\title{
Distinct Identity of GLP-1R, GLP-2R, and GIPR Expressing Cells and Signaling Circuits Within the Gastrointestinal Tract
}

\section{OPEN ACCESS}

Edited by:

Sameer Mohammad,

King Abdullah International Medical Research Center (KAIMRC),

Saudi Arabia

Reviewed by:

Ankit Malik,

University of Chicago, United States

Venkateswarlu Kanamarlapudi, Swansea University, United Kingdom

*Correspondence:

Erin E. Mulvihill

emulvihi@uottawa.ca

Specialty section:

This article was submitted to

Signaling,

a section of the journal

Frontiers in Cell and Developmental

Biology

Received: 01 May 2021

Accepted: 16 August 2021

Published: 29 September 2021

Citation:

Morrow NM, Hanson AA and

Mulvihill EE (2021) Distinct Identity of GLP-1R, GLP-2R, and GIPR

Expressing Cells and Signaling

Circuits Within the Gastrointestinal

Tract. Front. Cell Dev. Biol. 9:703966.

doi: 10.3389/fcell.2021.703966

\author{
Nadya M. Morrow ${ }^{1,2}$, Antonio A. Hanson ${ }^{1,2}$ and Erin E. Mulvihill1,2,3,4* \\ ' Energy Substrate Laboratory, University of Ottawa Heart Institute, Ottawa, ON, Canada, ${ }^{2}$ Department of Biochemistry, \\ Microbiology and Immunology, University of Ottawa, Ottawa, ON, Canada, ${ }^{3}$ Montreal Diabetes Research Center \\ CRCHUM-Pavillion R, Montreal, QC, Canada, ${ }^{4}$ Centre for Infection, Immunity and Inflammation, University of Ottawa, \\ Ottawa, ON, Canada
}

Enteroendocrine cells directly integrate signals of nutrient content within the gut lumen with distant hormonal responses and nutrient disposal via the production and secretion of peptides, including glucose-dependent insulinotropic polypeptide (GIP), glucagon-like peptide 1 (GLP-1) and glucagon-like peptide 2 (GLP-2). Given their direct and indirect control of post-prandial nutrient uptake and demonstrated translational relevance for the treatment of type 2 diabetes, malabsorption and cardiometabolic disease, there is significant interest in the locally engaged circuits mediating these metabolic effects. Although several specific populations of cells in the intestine have been identified to express endocrine receptors, including intraepithelial lymphocytes (IELS) and $\alpha \beta$ and $\gamma \delta$ T-cells $(G / p 1 r+)$ and smooth muscle cells $(G / p 2 r+)$, the definitive cellular localization and co-expression, particularly in regards to the Gipr remain elusive. Here we review the current state of the literature and evaluate the identity of Glp1r, Glp2r, and Gipr expressing cells within preclinical and clinical models. Further elaboration of our understanding of the initiating G-protein coupled receptor (GPCR) circuits engaged locally within the intestine and how they become altered with high-fat diet feeding can offer insight into the dysregulation observed in obesity and diabetes.

Keywords: glucagon-like peptides, intestine, incretins, metabolism, glucose-dependent insulinotropic polypeptide

Abbreviations: 5-HT, serotonin receptor; ApoB48, apolipoprotein B48; ATP, adenosine triphosphate; AUC, area under curve; cAMP, cyclic adenosine monophosphate; ChAT, choline-acetyltransferase; CNS, central nervous system; DIRKO, double incretin receptor knockout; DPP4, dipeptidyl peptidase 4; DS, dextrane sulfate; EGFR, tyrosine kinase IGF1R/ErbB; eNOS, endothelial nitric oxide synthase; ER, endoplasmic reticulum; FABP5, fatty acid-binding protein 5; FFA, free fatty acid; FFAR1, free-fatty acid receptor 1; FFAR2, free-fatty acid receptor 2; FFAR4, free-fatty acid receptor 4; GAL galinin receptor; Gcg, preproglucagon; GCGR, glucagon receptor; GIP, glucose-dependent insulinotropic polypeptide; GIPR, glucose-dependent insulinotropic polypeptide receptor; GLP-1, glucagon-like peptide 1; GLP-1R, glucagon-like peptide 1 receptor; GLP-2, glucagon-like peptide 2; GLP-2R, glucagon-like peptide 2 receptor; GPCR, G-protein coupled receptor; GPR119, G-protein coupled receptor 119; GPR93, G-protein coupled receptor 93; GPRC6A, G-protein coupled receptor family C group 6 subtype A; IEL, intraepithelial lymphocyte; IL-1 $\beta$, interleukin 1 beta; IL-6, interleukin 6; KGF, keratinocyte growth factor; LCFA, long-chain fatty acid; LPL, lipoprotein lipase; LPS, lipopolysaccharide; nNOS, neuronal nitric oxide synthase; NOD, non-obese diabetic; OGTT, oral glucose tolerance test; PBS, phosphate-buffered saline; PC1/3, prohormone convertase 1/3; PC2, prohormone convertase 2; Pdx1, pancreatic and duodenal homeobox 1; Rfx6, regulatory factor X6; RYGB, Roux-en-Y gastric bypass; SCFA, short-chain fatty acid; SGLT1, sodium glucose co-transporter 1; SP, substance P; STAT, subtherapeutic antibody therapy; T2DM, type 2 diabetes mellitus; TG, triglyceride; TPN, total parenteral nutrition; TRL, triglyceride rich lipoprotein; VIP, vasoactive intestinal polypeptide; VSG, vertical sleeve gastrectomy; $\alpha$ SMA, smooth muscle actin. 


\section{INTRODUCTION}

Extending between the stomach and the colon lies among the most significant hormone-producing and immunological organs responsible for nutrient digestion and absorption: the small intestine. Within the small intestine lumen, the surface area is ideally maximized to enhance nutrient absorption through villi and microvilli, which increase intestinal surface area by 30600-fold (Kiela and Ghishan, 2016). A single layer of epithelial cells lines the surface of each villus to serve as the gateway for controlled nutrient absorption and a barrier to dietary antigens and diverse microorganisms (Turner, 2009). Absorptive enterocytes populate the villus tip and account for $>80 \%$ of intestinal epithelial cells. The remaining mature cell types include mucin-producing goblet cells, antimicrobial defensins-producing Paneth cells, peptide-hormone-producing enteroendocrine cells, and cytokine-producing tuft cells which reside throughout the epithelium (Ensari and Marsh, 2018). Shallow invaginations surrounding each villus are intestinal crypts and the site of cell division: highly mitotic stem cells that give rise to progenitor cells, which in turn proliferate to become mature epithelial cells (Gehart and Clevers, 2019). The continuous supply of progenitor and new epithelial cells physically promotes the transit of the latter from the crypts up to the villus tip, where they populate the newly vacant area of previously shed apoptotic epithelial cells (Gehart and Clevers, 2019). Therefore, in addition to the maximized absorptive surface area, the constantly renewing barrier protects the internal environment from the harsh conditions of the intestinal lumen. This single epithelial layer sits on a basement membrane surrounding a connective tissue core called the lamina propria, which contains lymphocytes and innate immune cells (Ensari and Marsh, 2018). Each villus is supplied by an arteriole that forms a capillary network, a venule that drains into larger vessels at the crypts (Ensari and Marsh, 2018), and 1-2 lacteals, which are terminal lymphatic vessels of the mesenteric network. Pericytes coat villus blood vessels while smooth muscle cells coat lacteals. The lamina propria also contains connective tissue scaffolds, enteric nerves, fibroblasts, and smooth muscle cells (BernierLatmani and Petrova, 2017). The lamina propria is encapsulated by a myofibroblast shell that directly contacts the vascular network. From the villus tip to the muscularis mucosa, onto which villi are anchored, is considered the mucosal layer. The submucosal layer contains blood and lymphatic vessels and a plexus of parasympathetic nerves (Bernier-Latmani and Petrova, 2017), while the smooth muscle cell-rich muscularis propria allows for contractile peristalsis (Collins et al., 2021). The final outer layer of the intestine is the serosa, composed of loose connective tissue and squamous epithelial cells (Collins et al., 2021), which is continuous with the mesentery. The mesentery supports the intestine in the peritoneum and also contains blood vessels, nerves, and lymphatics (Argikar and Argikar, 2018). The coordination of barrier function with nutrient absorption and transit is governed by a complex integration of signals, including local enteroendocrine production of peptide hormones, which impacts both the dynamic and highly efficient process of nutrient assimilation.
In addition to its expression in the pancreas, proglucagon is also produced in enteroendocrine $\mathrm{L}$ cells throughout the small and large intestine (Jorsal et al., 2018). Here, posttranslational processing of the 160 amino acid proglucagon by prohormone convertase 1/3 (PC1/3) yields active peptides glicentin, glucagonlike peptide 1 (GLP-1), intervening peptide 2 (IP2), and glucagonlike peptide 2 (GLP-2) (Mojsov et al., 1986; Orskov et al., 1986). Evidence for gut-derived glucagon is observed in patients with a total pancreatectomy during a glucose tolerance test (Lund et al., 2016). GLP-1, first identified from amino acids 1-37 and 1-33 (Drucker et al., 1986), is active upon N-terminal truncation, where GLP-1(7-37) and GLP-1(7-36)amide are physiologically active with well-defined roles in promoting nutrient-stimulated insulin secretion (Drucker et al., 1987; Holst et al., 1987). The active form of GLP-2 in tissue and circulation is the complete 1-33 amino acid (Brubaker et al., 1997) upon C-terminal truncation of 2 amino acids (Orskov et al., 1989b) with a welldefined role of acting locally to promote nutrient uptake, barrier function and gut growth.

Glucose-dependent insulinotropic polypeptide (GIP) is a peptide hormone expressed and secreted by intestinal $\mathrm{K}$ enteroendocrine cells. GIP is derived from a 144 amino acid (rodent) (Higashimoto et al., 1992; Higashimoto and Liddle, 1993; Tseng et al., 1993) or 153 amino acid (human) (Takeda et al., 1987) precursor, proGIP. Most K cells express PC1/3, which cleaves proGIP at Arg65, resulting in the biologically active GIP(1-42) (Ugleholdt et al., 2006) and stored in secretory granules ( $450 \mathrm{~nm}$ ) (Buchan et al., 1978). A small population of $\mathrm{K}$ cells express $\mathrm{PC} 2$ instead of $\mathrm{PC} 1 / 3$, resulting in GIP(1-31), which is amidated by peptidyl-glycine $\alpha$-amidating monooxygenase, resulting in GIP(1-30) (Fujita et al., 2010). Initially discovered in 1973 for its role in inhibiting gastric acid secretion in excised canine stomach pouches, and later shown to not have this effect in humans (Meier et al., 2004a), GIP promotes nutrient-stimulated insulin secretion and increases glucagon secretion in the fasted state but not in patients with type 2 diabetes (Baggio and Drucker, 2007; Christensen et al., 2011).

The physiological concentrations of the peptide hormones GIP, GLP-1, and GLP-2, are tightly controlled by the nutrientsensing abilities of their respective enteroendocrine cells. Additionally, the serine protease dipeptidyl peptidase 4 (DPP4) limits the bioavailability of GIP, GLP-1, and GLP-2 by cleaving the first two amino acids, rendering them inactive (Deacon et al., 1995a; Knudsen and Pridal, 1996; Hansen et al., 1999). In healthy humans, GIP has a circulating half-life of $7 \mathrm{~min}$ (Meier et al., 2004b), GLP-1 has a circulating half-life of 1-2 min (Deacon et al., 1995b), and GLP-2 has a circulating half-life of 7 min (Drucker et al., 1997; Hartmann et al., 2000). GIP concentrations are much greater than GLP-1 in the postprandial state (Meek et al., 2021). Prolonged activation of GLP-1, GLP-2, and GIP receptors is achieved through receptor agonists resistant to DPP4 cleavage or through compounds that inhibit DPP4 activity (Jeppesen et al., 2005; Baggio and Drucker, 2007).

This review highlights the biology and paracrine roles of GLP1, GIP, and GLP-2 in integrating the response to food intake with the maintenance of the structure and function of the gut as it relates to nutrient absorption. We critically assess experiments 
reporting the identification and role(s) of GPCRs: GIP receptor (GIPR), GLP-1 receptor (GLP-1R) and GLP-2 receptor (GLP$2 \mathrm{R}$ ) in intestinal physiology. We also emphasize both preclinical and clinical studies identifying how agonists to these receptors transduce their metabolic actions. We limit our discussion to intestinal biology and the resulting metabolic phenotypes and refer readers interested in other aspects of the GLP-1R, GLP$2 \mathrm{R}$ and GIPR biology to access other excellent publications (Campbell, 2021; Ghislain and Poitout, 2021; Gribble and Reimann, 2021; McLean et al., 2021).

\section{GUT HORMONAL RESPONSES TO NUTRIENTS}

Enteroendocrine cells are highly sensitized to nutrient intake due to their polarized shape, direct contact with the lumen, and proximity to the vasculature for peptide secretion. Upon ligandreceptor binding and depolarization, hormone-containing granules fuse with the lateral and basal membrane for discharge into the villus capillaries (Paternoster and Falasca, 2018). This idealistic design favors rapid and precise peptide delivery in circulation to initiate signaling through their respective receptors to control metabolism. Additionally, enteroendocrine cells are equipped with GPCRs and transporters to sense the macronutrients and release the appropriate hormones (Spreckley and Murphy, 2015). These include: G-protein coupled receptor (GPCR) family C group 6 subtype A (GPRC6A), Taste Rs (amino acids), G-protein coupled receptor 93 (GPR93) (peptones), free-fatty acid receptor 2 (FFAR2), free-fatty acid receptor 3 (FFAR3), short-chain fatty acid (SCFA), free-fatty acid receptor 1 (FFAR1), free-fatty acid receptor 4 (FFAR4), long-chain fatty acid (LCFA) and G-protein coupled receptor 119 (GPR119) [oleoylethanolamide (oea)] are some of the macronutrient-sensing receptors present on enteroendocrine cells (Spreckley and Murphy, 2015). First, we begin with an overview of the regulation of the synthesis, secretion, and location of these peptides.

\section{GIP Expression and Secretion}

GIP mRNA (Tseng et al., 1993) and concentration (Bryant et al., 1983) are enriched in duodenal and jejunal mucosal tissues in rodents and humans compared to the distal ileum (Figure 1). Forty-eight hours of fasting in rats significantly decreases Gip mRNA $(\sim 44 \%)$ in the proximal small intestine compared to rats maintained on a chow diet. At the same time, GIP peptide concentrations do not change with fasting or feeding (Higashimoto et al., 1995), suggesting that synthesis and secretion are relatively synchronized. K-cells in the proximal small intestine contain more GIP protein and secrete more GIP in response to intestinal lard oil perfusion than distal $\mathrm{K}$ cells (Iwasaki et al., 2015). GIP expression is significantly greater in both the small intestine and colon of patients with Type 2 diabetes than healthy individuals (Jorsal et al., 2018). Interestingly, in patients with type 2 diabetes, the density of PC1/3-positive cells decreases while both the expression and density of PC-2 positive cells increases (Jorsal et al., 2018). Nutrient stimulation of GIP secretion has also been reviewed here (Pais et al., 2016; Reimann et al., 2020).

In $\mathrm{K}$ cells, regulatory factor $\mathrm{X} 6(\mathrm{Rfx} 6)$ is a transcription factor that binds to the Gip promoter to increase Gip mRNA expression (Suzuki et al., 2013). Intestine-specific gene transfer experiments of pancreatic and duodenal homeobox-1 $(P d x 1)$ siRNA in 8-10-week-old mice reveal that posteriori suppression of Pdx1 decreases $\mathrm{K}$-cell number, intestinal GIP protein and mRNA expression, and GIP secretion in response to an oral glucose tolerance test (OGTT) (Ikeguchi et al., 2018). The number of K cells and their Gip mRNA content increases with age, which corresponds to the GIP hypersecretion observed in 1 year old mice compared to 3-4-month-old mice (Ikeguchi et al., 2018). Moreover, transcription factor $P d x 1$, but not $R f x 6$ mRNA increases with age in K cells (Ikeguchi et al., 2018). Both dietary fat and carbohydrate stimulate GIP secretion (Pederson et al., 1975; Brown and Otte, 1979; McCullough et al., 1983). Intraduodenal perfusion of $20 \%$ Lipomul significantly increases duodenal Gip mRNA at 30 and 60 min compared to saline control (Tseng et al., 1993). Both glucose (4-fold) and fat (2.5-fold) ingestion increase Gip mRNA expression compared to chow-diet feeding (Higashimoto et al., 1995). High-fat feeding does not increase K-cell number in mice, instead, it increases GIP protein content and mRNA expression, which correlates to increased $R f x 6$ and $P d x 1$ mRNA expression (Suzuki et al., 2013). Therefore, through different mechanisms, both diet-induced obesity and aging act on the gut to increase GIP reserves for secretion into circulation.

\section{Nutrient Stimulated GIP Secretion}

GIP secretion increases more rapidly in response to simple, fastabsorbing carbohydrates compared to complex, slow-absorbing carbohydrates (Collier et al., 1984). Plasma GIP levels rise significantly higher upon oral fat consumption compared to glucose in mice (Shibue et al., 2015) and in humans (Yamane et al., 2012). Further, ingestion of a mixed carbohydrate and fat meal significantly increases plasma GIP levels compared to carbohydrates alone in healthy humans (Collier et al., 1984) but this increase is not as great as ingestion of fat alone in healthy humans (Creutzfeldt et al., 1978). GIP secretion in response to oral fat is greater in patients with obesity and glucose intolerance, and does not change with the addition of glucose to the meal (Creutzfeldt et al., 1978).

GIP concentrations in the bloodstream are the highest in hepatic portal plasma, however, lymph GIP concentrations are 3-fold higher upon the same stimulus (D'Alessio et al., 2007; Lu et al., 2008), indicating peptide transit from $\mathrm{K}$ cells to villus lacteals. Intraduodenal delivery of a bolus of dextrin and a bolus of Liposyn $(20 \%)$ in rats each induce $\sim 800$ and $\sim 400 \mathrm{pg} / \mathrm{mL}$ peaks, respectively, in lymph GIP concentrations at $60 \mathrm{~min}$ (Lu et al., 2008). However, the peak secretion rate occurs at $30 \mathrm{~min}$ for Liposyn $(1,159 \pm 393 \mathrm{pg} / \mathrm{h})$ and at $60 \mathrm{~min}$ for dextrin $(2,410 \pm 566 \mathrm{pg} / \mathrm{h})$. The combination of dextrin and Liposyn delivery significantly increases GIP secretion at $30 \mathrm{~min}$ $(2,094 \pm 241 \mathrm{pg} / \mathrm{h})$ and at $60 \mathrm{~min}(8,027 \pm 1,057 \mathrm{pg} / \mathrm{h})$ compared to saline, dextrose alone, and Liposyn alone (Lu et al., 2008). These data suggest that glucose and lipids stimulate $\mathrm{K}$ cells 


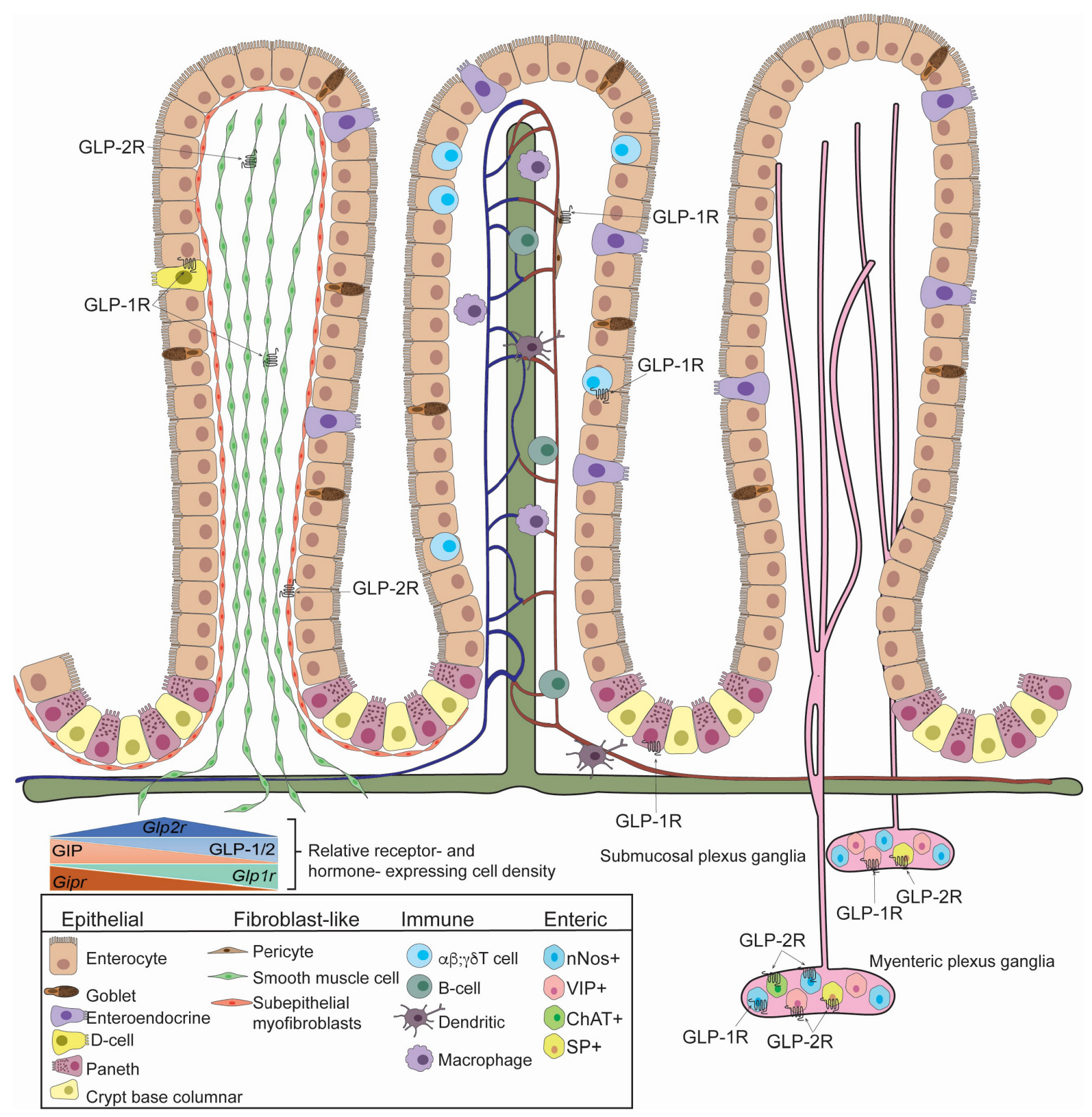

FIGURE 1 | GLP-1R and GLP-2R-expressing cells in the small intestine identified in mice. Villus architecture is organized as fibroblast-like cells (Left), blood, lymph and immune cells (Middle), enteric cells (Right). GLP-1R is expressed in somatostatin-secreting enteroendocrine cells, smooth muscle cells, pericytes, Paneth cells, $T \alpha \beta$ cells, $T \gamma \delta$ cells, submucosal and myenteric neurons. GLP-1R is detected in neuronal nitric oxide (nNOS)+ neurons. GLP-2R is detected in smooth muscle cells, subepithelial myofibroblasts, submucosal and myenteric neurons. Specifically, GLP-2R is expressed in nNOS+ cells, vasoactive intestinal polypeptide (VIP)+ cells, choline-acetyltransferase (ChAT)+ cells, and substance $\mathrm{P}(\mathrm{SP})+$ cells. The relative receptor- and hormone- expression cell density within the small intestine is depicted (inset). Studies highlighted here did not determine co-expression of GLP-1R and GLP-2R and specific identity of GIPR-expressing cells is unclear.

differently, therefore potentiating release when administered together. Indeed, preventing micelle formation via common bile duct ligation abolishes GIP secretion upon a lard gavage compared to sham controls, independent of meal transit (Shibue et al., 2015). As dietary fatty acids are assembled into lipoproteins in intestinal enterocytes for subsequent circulatory transport, blocking lipoprotein transit from endoplasmic reticulum (ER) to Golgi by Pluronic L- 81 in rats robustly reduces ( $\sim 4.5$-fold) lymph GIP levels and secretion rates in response to Liposyn to levels similar to saline controls (Lu et al., 2012). Therefore, GIP secretion from $\mathrm{K}$ cells in response to Liposyn requires post-Golgi chylomicron transit in enterocytes, not lipid absorption alone ( $\mathrm{Lu}$ et al., 2012). GIP secretion increases in response to chylomicrons alone and the presence of glucose in both murine and human duodenal cultures in a dose-dependent fashion (Psichas et al., 2017). Glucose stimulation of chylomicron secretion is well 
documented (Robertson et al., 2003; Stahel et al., 2019; Xiao et al., 2019) where glucose promotes chylomicron secretion from lipid stores in enterocytes (Stahel et al., 2019), which may provide additional stimulus for GIP secretion. Co-intraduodenal infusion of mixed nutrients (carbohydrate, dextrose) and lipid (20\% Liposyn) in rats significantly increase GIP secretion in lymph to a greater extent than either nutrient at the same meal caloric value alone, suggesting a synergistic effect (Lu et al., 2008). Consistent with glucose-stimulated chylomicron secretion, lymph TG values are the same when Liposyn accounts for half of the meal calories (the other half being dextrose) compared to a full Liposyn meal (Lu et al., 2008). Experiments measuring glucose-stimulated GIP secretion after inhibiting chylomicron release (Pluronic 818) or basolateral hydrolysis of chylomicrons (poloxamer-407) may help delineate the exact contribution of each nutrient. Nevertheless, the requirement of chylomicron formation for GIP secretion from proximal $\mathrm{K}$ cells corresponds to a location-specific stimulus. Taken together, these studies demonstrate the complex integration of pathways governing GIP secretion and intestinal lipid metabolism.

The free fatty acid receptor GPR120 is enriched in proximal K cells while GPR40, GPR41, and GPR43 are significantly enriched in distal $\mathrm{K}$ cells (Iwasaki et al., 2015). GIP secretion is unaffected by FFA1 agonism (Am-1638) or antagonism (GW1100) in primary murine duodenal cultures (Psichas et al., 2017). GIP concentration in plasma over $120 \mathrm{~min}$ decreases by $75 \%$ in Gpr120-/- mice upon lard oil gavage compared to wild-type mice (Iwasaki et al., 2015). Correspondingly, intestinal perfusion experiments in $\mathrm{Gpr}_{120^{-/-}}$mice reveal that GIP secretion is significantly reduced from both proximal and distal regions of the small intestine compared to wild-type controls (Iwasaki et al., 2015). Similarly, oral pretreatment with a GPR120 partial antagonist, grifolic acid methyl ether, reduces GIP secretion by $80 \%$ in response to lard oil gavage (Iwasaki et al., 2015). All GIP+ cells express fatty acid-binding protein 5 (FABP5) (Shibue et al., 2015). While whole-body elimination of FABP5 in mice does not impact GIP content or $\mathrm{K}$ cell number, these mice secrete significantly less GIP into plasma $60 \mathrm{~min}$ after a lard gavage compared to wild-type controls (Shibue et al., 2015). Ex vivo duodenal segments from Fabp5 $5^{-/-}$mice secrete significantly less GIP in response to oleic acid with $4 \mathrm{v} / \mathrm{v} \%$ bile in media than tissues isolated from wild-type mice (Shibue et al., 2015). These data suggest that micelle-facilitated fatty acid uptake via FABP5 in response to luminal lipids significantly contributes to meal-stimulated GIP secretion (Shibue et al., 2015) (Figure 2).

Glucose stimulates GIP secretion only when administered orally, therefore requiring apical exposure to K cells. Curiously, intraduodenal infusion of glucose in healthy men does not significantly increase plasma GIP levels from baseline (Herrmann et al., 1995), suggesting a transit time dependency for glucosestimulated GIP secretion. Glucose injection in the upper intestine significantly increases plasma GIP levels while glucose injection in the colon does not (Moriya et al., 2009). Perfusion of glucose, sucrose, galactose, maltose, 3-O-methylglucose, and $a$ - or $B$-methylglucoside significantly stimulate GIP secretion, while mannose, 6-deoxygalactose, 2-deoxyglucose, myoinositol, fructose or lactose do not (Sykes et al., 1980). Therefore, active transport by the sodium-dependent hexose pathway is required for GIP secretion (Sykes et al., 1980). Indeed, sodium glucose co-transporter 1 (SGLT1) receptor is expressed only on the apical side of $\mathrm{K}$ cells and oral gavage of SGLT1 substrate, a-methyl-D-glucopyranoside, stimulates GIP secretion (Moriya et al., 2009). The necessity for apical glucose transport is demonstrated in Sglt1 ${ }^{-/-}$mice, where glucose-stimulated GIP secretion is eliminated and levels rise only to the same extent as observed in the saline control (Gorboulev et al., 2012). Genetic elimination of $K_{\text {ATP }}$ channels (Kir6.2 $2^{-/-}$mice) significantly increases glucose absorption and glucose-stimulated GIP secretion, through a compensatory increase in duodenal Sglt1 mRNA expression (Ogata et al., 2014). Preventing glucose absorption with phloridizin abolishes glucose-stimulated GIP secretion in healthy wild-type (Sykes et al., 1980) and Kir6.2-/mice (Ogata et al., 2014), even in the presence of $a$-methyl-Dglucopyranoside (Moriya et al., 2009). Similar to humans, mice and rats with diabetes secrete more GIP in response to oral glucose. Fructose transporter, GLUT5, is expressed on K-cells; however, fructose does not stimulate GIP secretion in healthy humans, rats, or mice (Kuhre et al., 2014; Seino et al., 2015). Fructose significantly increases GIP secretion in streptozotocintreated, hyperglycemic mice in a $\mathrm{K}_{\mathrm{ATP}}$-dependent manner (Seino et al., 2015) and in ob/ob mice (Flatt et al., 1989). This is further supported by the inability of phlorizin to prevent glucoseinduced GIP secretion in streptozotocin-treated, hyperglycemic mice, where complete blockage of GIP secretion is only achieved in these mice upon both phlorizin and $\mathrm{K}_{\mathrm{ATP}}$ channel activation (diazoxide) (Ogata et al., 2014).

Non-nutrient promoters of GIP secretion include oral administration of $\mathrm{ZnCl}_{2}$ to non-fasted mice, which increases GIP secretion $26 \%$ via $\mathrm{K}$ cell expression of GPR39 (Moran et al., 2019). Additionally, associated metabolic improvements with $\mathrm{ZnCl}_{2}$ administration are lost in $\mathrm{Gipr}^{-/-}$mice (Moran et al., 2019). Galinin is a centrally and peripherally synthesized neuropeptide and its receptor $\left(\mathrm{GAL}_{1}\right)$ is expressed in $\mathrm{K}$ cells (Psichas et al., 2016). Both galinin and $\mathrm{GAL}_{1}$ agonist (M617) significantly inhibit IBMX-stimulated GIP secretion from primary duodenal cultures (Psichas et al., 2016). Oral administration of progesterone significantly increases glucosestimulated GIP secretion (5 $\mathrm{min}$ ) in male wild-type and Glp1r-/-Gipr-/- (double incretin receptor knockout; DIRKO) mice, but not in Glp1r-/- mice (Flock et al., 2013) (Figure 2).

\section{GIP Secretion and the Microbiome}

Glucose-dependent insulinotropic polypeptide levels are increased with subtherapeutic antibiotic therapy (STAT) (Cho et al., 2012) while other hormones are unaffected. It is suspected that levels are greater due to the increased abundance of Firmicutes and subsequent SCFA production (Martin et al., 2019), however, further studies to confirm this hypothesis are required.

\section{Expression and Secretion of GLP-1 and GLP-2}

GLP-1+ cells reside in crypts and the villus epithelium; their density increases distally with the highest abundance in the ileum 


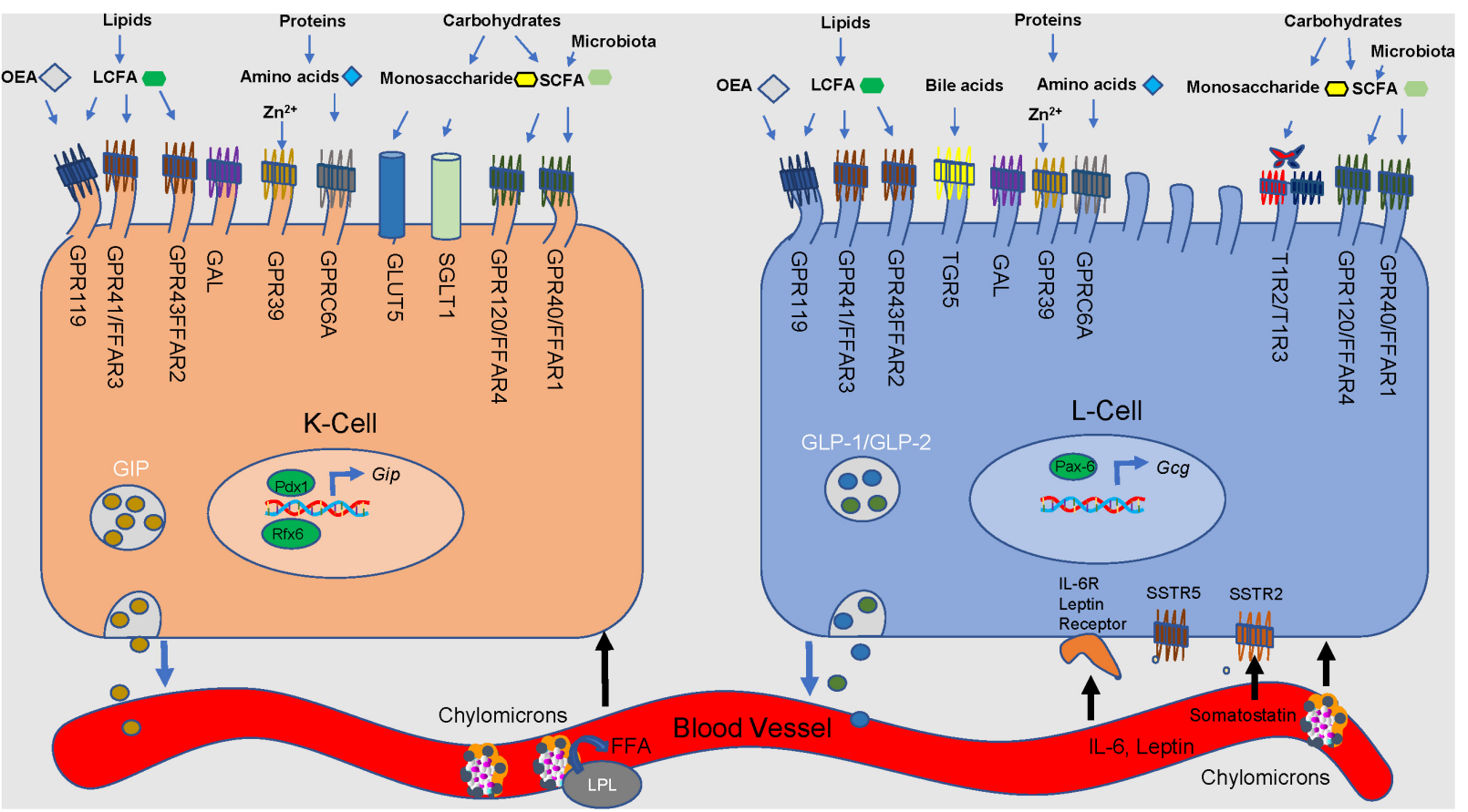

FIGURE 2 | Nutrient stimulation of GIP from K cells and GLP-1 and GLP-2 from L cells. Microvilli protrude from the apical side of the cell, extending toward the lumen. Incoming macronutrients from the lumen are detected and sensed by receptors present on the apical border. Carbohydrates are divided into monosaccharides and short-chain fatty-acids (SCFA). Glucose is transported through the sodium-glucose linked transporter (SGLT1). Glucose passes through the glucose transporter 2 (GLUT2) present on the basolateral membrane, and into the bloodstream. GLUT5 is responsible for sensing fructose. Present on only $L$ cells, sweet receptors (T1R2/T1R3) also sense glucose. Short-chain fatty acids (SCFA) are derived from microbial fermentation, and are sensed by the free fatty acid receptors (GPR40/FFAR1 and GPR120/FFAR4). Long-chain fatty-acids are sensed by GPR43/FFAR2 and GPR41/FFAR3, along with G-protein coupled receptor 119 (GPR119). GPR119 is also a receptor for oleoylethanolamide (OEA). Amino acids are detected by GPR9C6A. GPR39 and Takeda G-protein coupled receptor 5 (TGR5) detect luminal zinc and bile acids, respectively. Galanin receptor (GAL) acts to inhibit both GLP-1 and GIP secretion. Lipoprotein lipase is involved in the production of LCFA and monoacylglycerols. Somatostatin receptors 2 and 5 (SSTR2\&5) sense somatostatin from D cells. Regulatory factors x6 (Rfx6) and insulin promoter factor 1 (Pdx1) influence GIP expression and secretion.

in rodents (Figure 1) and the colon in humans (Eissele et al., 1992). Within L cells, GLP-1 is stored in granules (Eissele et al., 1992) in its active form (7-36 amide) in the small (Orskov et al., 1989a) and large intestine (Deacon et al., 1995b). Forty-eight hours of fasting in rats significantly reduces ileal Gcg mRNA (25$50 \%$ ), which was associated with a $41-60 \%$ decrease in plasma bioactive GLP-2 (Nelson et al., 2008). Both plasma GLP-2 and ileal $G c g$ mRNA levels were restored upon 2 days of refeeding or 4 days of continuous intragastric, but not intravenous, refeeding with total parenteral nutrition (TPN) solution (32\% energy from fat 68\% energy from dextrose) (Nelson et al., 2008). Colonic L cells contain twice as much GLP-1 peptide than proximal intestine L cells (Reimann et al., 2008). Both colonic GCG expression and GLP-1+ cell density increase in patients with type 2 diabetes compared to healthy individuals (Jorsal et al., 2018). By contrast, while PCSK $1 / 3$ mRNA increases in patients with diabetes compared to healthy individuals, the density of PC1/3-positive cells decreases (Jorsal et al., 2018), suggesting a posttranslational impact on GLP-1 availability. GLP-1+ cells are also found in the stomach fundus where concentrations are higher than in the antrum in both diet-induced obese rats and humans with obesity (Ribeiro-Parenti et al., 2021). In dietinduced obese mice, IBMX-stimulated GLP-1 release ex vivo is completely abrogated in the antrum (Ribeiro-Parenti et al., 2021). Interestingly, the remodeling of the gastric mucosa following Roux-en-Y gastric bypass (RYGB) bariatric surgery in humans is accompanied by a $\sim 2$-fold increase in fundic GLP-1 positive cells; this increase is not observed in patients following vertical sleeve gastrectomy (VSG) surgery (Ribeiro-Parenti et al., 2021). This increase in fundic mucosal GLP-1 following RYGB but not VSG was consistent in diet-induced obese rats, where instead, VSG surgery induced a 50\% increase in GLP-1+ cells in the antrum (Ribeiro-Parenti et al., 2021). This increase was associated with a 1.5-fold increase in portal plasma GLP-1 upon gastric glucose stimulation in diet-induced obese VSG rats compared to diet-induced obese sham controls, suggesting that antral GLP-1 producing cells contribute significantly to portal GLP-1 (RibeiroParenti et al., 2021). However, further experiments preventing GLP-1 secretion from ileal L cells will be required to precisely assess the contribution from the stomach after surgery.

\section{Nutrient Stimulated GLP-1 Secretion}

In healthy men, oral ingestion of corn oil induces a 1,000\% increase in the early phase of GLP-1 secretion, which does not return to baseline even after 120 min (Herrmann et al., 1995). In the same study, oral ingestion of a mixed meal containing 
soybean oil, casein, and glucose induces a rapid $\sim 6$-fold increase in GLP-1 levels, which is lower than corn oil alone and also leads to a return to baseline (Herrmann et al., 1995). Ileal luminal perfusion of a mixed meal in rats induces a rapid rise (2-fold) in portal plasma GLP-1 in 30 min (Herrmann et al., 1995). A 20\% infusion of Intralipid in the perfused rat ileum, however, does not significantly increase portal plasma GLP-1 from baseline (Herrmann et al., 1995), suggesting that since orally ingested fatty acids do not reach the ileum, a direct sensing mechanism for this lipid composition does not exist in the ileum or that GLP-1 in this experiment bypasses portal circulation. By contrast, experiments directly administering corn oil into either duodenal or ileal luminal compartments in anesthetized rats demonstrate significantly increased plasma GLP-1 (obtained from carotid artery) to the same extent from baseline (Roberge and Brubaker, 1993). Taken together, these studies demonstrate that either higher fatty acid concentration, mechanical stimulation, or a specific blood sampling pool is required to detect this response from the distal gut. While not often measured, the GLP-1/GLP-2 ratio (detecting C-terminal of GLP-1 and N-terminal of GLP2) remains consistent throughout an oral fat tolerance test, but interestingly significantly increases at 120 and $250 \mathrm{~min}$ during an OGTT in obese men (Matikainen et al., 2016). Additionally, in response to a meal, in patients with short bowel syndrome with a preserved colon (jejuno-colonic anastomosis), both baseline GLP-1 and GLP-2 are elevated with GLP-2 levels threefold greater than control patients (average concentration of $72 \mathrm{pmol} / \mathrm{L}$ ), which persists throughout the post-prandial period (Jeppesen et al., 2000).

Lymph fistula experiments in rats reveal post-prandial levels in intestinal lymph are 5-6 times higher for GLP-1 compared to portal venous plasma (D'Alessio et al., 2007; Lu et al., 2007). Similarly, GLP-2 concentrations in the lymph are significantly higher ( $\sim 2$-fold) than in blood at fasting and $2 \mathrm{~h}$ after $(\sim 3$ fold) duodenal infusion of perilla oil (Sato et al., 2013). The physiological advantage for lymph vs. blood secretion is not clear; however, DPP4 activity is significantly higher during fasting (20fold) and post-meal (3-fold) in plasma than in lymph (D'Alessio et al., 2007). Intraduodenal infusion of Liposyn significantly increases lymph flow, lymph GLP-1 levels and secretion rates before increases in lymph TG and lymph free fatty acid (FFA) compared to saline control are observed (Lu et al., 2012). Pluronic L-81 impairs lymphatic transport of TG without inhibiting fatty acid absorption or TG assembly (Tso et al., 1981; Hayashi et al., 1990), therefore leading to the accumulation of large apical lipid droplets in enterocytes (Tso et al., 1981). The addition of pluronic L-81 to the Liposyn infusion significantly reduces lymph flow to rates observed in saline control. It completely abolishes TG and FFA concentrations and delays the peak in lymph GLP-1 concentrations from 30 to $120 \mathrm{~min}$, with a $75 \%$ reduction in the rate at $30 \mathrm{~min}$, but secretion was the same at $60 \mathrm{~min}$ ( $\mathrm{Lu}$ et al., 2012). Overall, the addition of L-81 to Liposyn did not reduce the cumulative GLP-1 output to the same levels as saline controls, whereas GIP secretion was abolished (Lu et al., 2012).

In the presence of glucose, chylomicrons (10 and $100 \mu \mathrm{g} / \mathrm{mL}$ ) significantly increase GLP-1 secretion from GLUTag cells, murine duodenal cultures, and human duodenal cultures (Psichas et al.,
2017). Lipoprotein lipase ( $L p l)$ is highly expressed in duodenal L cells and GLUTag cells; both the lipase inhibitor orlistat and siRNA-mediated knockdown of Lpl significantly inhibits chylomicron-induced GLP-1 secretion in GLUTag cells (Psichas et al., 2017). LPL-mediated hydrolysis of chylomicrons yields long chain fatty acids and monoacylglycerols, which are ligands for FFA1 and GPR119. Indeed, L cells express free acid receptors Ffar1 and G-protein coupled receptor 119 (Psichas et al., 2017). FFA1 receptor signaling increases GLP-1 secretion with or without chylomicron treatment, as shown with FFAl agonist (AM-1638), FFA1 antagonist (GW110), and siRNA-mediated knockdown experiments in GLUTag cells (Psichas et al., 2017). While GPR119 activation stimulates GLP-1 secretion in primary duodenal cultures, activation is not absolutely required for GLP-1 secretion as shown by L cell specific knockout (Psichas et al., 2017). Additionally, inhibiting both FFA1 and GPR119 at the same time does not impact GLP-1 secretion upon chylomicron treatment in primary duodenal cultures (Psichas et al., 2017). Also, orlistat does not significantly impact chylomicronstimulated GLP-1 secretion in duodenal cultures, suggesting that LPL-mediated release of FFA1 and GPR119 ligands may be restricted to GLUTag cells (Psichas et al., 2017). However, in primary cultures, only the apical membrane of $L$ cells are exposed to chylomicrons (Psichas et al., 2017). Therefore, basolateral LPL access to chylomicrons may be required.

In healthy men, oral glucose significantly increases plasma total GLP-1 [GLP-1(1-36) and GLP-1(7-36)] levels after $30 \mathrm{~min}$; its rise is delayed compared to the rapid increase of circulating GIP (Herrmann et al., 1995). Compared to oral glucose, oral galactose and amino acids rapidly increase plasma GLP-1 levels (Herrmann et al., 1995). In healthy men, intraduodenal infusion of glucose induces a rapid 200\% increase in GLP-1 that returns to baseline by 30 min (Herrmann et al., 1995). Ileal luminal perfusion of a $5 \%$ glucose dissolved in saline in rats induces a rapid rise ( $\sim$-fold) in portal plasma GLP-1 in 30 min (Herrmann et al., 1995). This effect is lost when glucose is dissolved in distilled water (Herrmann et al., 1995). While significantly lower than portal GLP-1 secretion upon intraduodenally delivered glucose, delivering glucose directly to the stomach in anesthetized rats with a pylorus ligature induces a significant increase in portal GLP-1 [+133 pM vs. phosphate-buffered saline (PBS)] and gastric vein $(+140 \mathrm{pM}$ vs. PBS $)$ at 15 min compared to PBS control, where $\sim 1 / 2$ of this total GLP-1 in the gastric vein is the active peptide (Ribeiro-Parenti et al., 2021). Gastric mucosal cells produce proglucagon, GLP-1, and GLP-2 (RibeiroParenti et al., 2021). Despite GLP-1 concentration being higher in the fundus than the antrum, its release ex vivo upon IBMX stimulation increases to the same extent in both the fundus and antrum, suggesting a significant contribution to both portal and gastric GLP-1 (Ribeiro-Parenti et al., 2021). Intraduodenal administration of sucrose, sucralose, and the artificial sweetener PALSWEET each significantly increase lymph GLP-2 output compared to saline control (Sato et al., 2013).

A paracrine relationship exists between GLP-1-secreting L cells and somatostatin-secreting D-cells (Jepsen et al., 2019). Additionally, the somatostatin receptor Sstr5 expression is present in GLP-1-immunoreactive cells (Jepsen et al., 2019). 
GLP-1 secretion in response to intraduodenal infusion of glucose increases with somatostatin receptor antagonism (SSTr2 and SSTr5) (Jepsen et al., 2019). Similarly, somatostatin secretion is dependent on GLP-1R activation as its secretion is inhibited upon GLP-1R antagonist (exendin-9) treatment (Jepsen et al., 2019). Taken together, this relationship is regulated by $\mathrm{L}$ cell and $\mathrm{D}$ cell expression of SSTr 5 and GLP-1R, respectively. Additionally, these findings explain the increased endogenous GLP-1 release upon exendin-(9-39) treatment.

\section{Hormonal Stimulation of GLP-1 Secretion}

Plasma GLP-1 levels peak within 5-15 min of food ingestion, where certainly these nutrients do not reach the ileum to directly stimulate L cells (Borgstrom et al., 1957). A neuroendocrine loop exists in proximal-distal intestine to stimulate ileal L cells when dietary fat enters the duodenum (Roberge and Brubaker, 1993; Rocca and Brubaker, 1999). As previously mentioned, administration of corn oil to duodenal luminal compartments elicits the same plasma GLP-1 response compared to corn oil administration to ileal luminal compartments (Roberge and Brubaker, 1993). Despite the presence of L cells in the duodenum, they are not responsible for the GLP-1 release as removing the jejunum-ileum before infusing the duodenal compartment with fat prevents the observed increase of plasma GLP-1 (Roberge et al., 1996). Still, plasma GIP secretion in response to duodenal luminal administration occurs earlier than GLP-1 secretion (Roberge and Brubaker, 1993). Importantly, intravenous infusion of post-prandial levels of GIP increases plasma GLP-1 levels twofold, independent of blood glucose levels (Roberge and Brubaker, 1993), suggesting that GIP stimulates early GLP-1 secretion in response to duodenal luminal nutrients. Indeed, GLP-1 secretion is abolished upon corn oil infusion to the proximal duodenal compartment in vagotomized rats (Rocca and Brubaker, 1999). Electrical stimulation of the vagus nerve stimulates GLP-1 secretion, even in the absence of nutrients (Rocca and Brubaker, 1999). GIP can stimulate the first phase of GLP-1 secretion independent of the vagus nerve, but only when infused at suprapharmacological levels, as evidenced by the rapid rise and fall in plasma GLP-1 upon supraphysiological infusion of GIP in sham and vagotomized rats (Rocca and Brubaker, 1999). At physiological levels, infusion of GIP does not stimulate GLP-1 secretion in vagotomized rats compared to the peak observed at $10 \mathrm{~min}$ in the sham controls (Rocca and Brubaker, 1999). Curiously, ingestion of $200 \mathrm{~mL}$ of pure water increases late phase plasma GLP-1, while GIP secretion is unchanged (Herrmann et al., 1995), suggesting a GIP-independent and potentially mechanically-mediated increase in GLP-1.

Leptin increases GLP-1 secretion in fetal rat intestinal cells, GLUTag, and NCI-H716 human enteroendocrine cells, all of which express a functional leptin receptor in GLP-1+ cells (Anini and Brubaker, 2003). Leptin (1 mg/kg, i.p.) increases fasting GLP-1 secretion 1.8-fold compared to saline control, reaching $6 \mathrm{pmol} / \mathrm{L}$ at $120 \mathrm{~min}$, which increases even further in leptindeficient mice $(o b / o b)$ (Anini and Brubaker, 2003). Therefore, leptin appears to induce the later phase of GLP-1 secretion compared to the early peak upon GIP treatment, which may be important for potentiating the leptin-stimulated reduction in food intake. Interestingly, leptin treatment significantly increases water intake in healthy rats (Sivitz et al., 1997), which may link the late-phase GLP-1 secretion induced by both leptin and water. Additionally, while high-fat fed mice with leptin resistance display increased GLP-1 content in the ileum and the colon, both fasting and glucose-stimulated GLP-1 secretion are significantly reduced in these mice (Anini and Brubaker, 2003), which may provide a link between leptin resistance in L cells and the reduced late phase (60-160 min) total and active GLP-1 secretion in patients with diabetes compared to healthy individuals (Vilsboll et al., 2001).

Similar to K cells, L cells also express the Galinin receptor, $\mathrm{GAL}_{1}$, and its activation via Galinin treatment or $\mathrm{GAL}_{1}$ agonist (M617) treatment prevents the accumulation of cyclic adenosine monophosphate (cAMP) in L cells within primary duodenal cultures in response to the adenylyl cyclase activator, forskolin and inhibits GLP-1 secretion from primary duodenal and ileal cultures (Psichas et al., 2016).

\section{Inflammation and GLP-1 Secretion}

Links between inflammation, the gut microbiota and GLP1 secretion have also been reported (Everard et al., 2011; Greiner and Backhed, 2016; Wu et al., 2018; Covasa et al., 2019; Martchenko et al., 2020). Indeed, lipopolysaccharide (LPS) acutely induces GLP-1 secretion (Nguyen et al., 2014). This was demonstrated to be dose- and time-dependent, where LPSinduced increases in circulating IL-6 (30 min) preceded that of both total and active GLP-1 (120 min) (Kahles et al., 2014). LPS also stimulates the release of IL-1 $\beta$, where the latter also increases plasma GLP-1 upon i.p. injection in mice to a greater extent than IL-6 injection (Kahles et al., 2014). However, loss of IL$1 \mathrm{R}$ signaling does not impact LPS-mediated GLP-1 secretion, as shown in $I l 1 r^{-/-}$mice while neither LPS nor IL-1 $\beta$ stimulate GLP-1 secretion in $\mathrm{Il}^{-/-}$mice (Kahles et al., 2014). Similarly, IL-6, but not LPS or IL-1 $\beta$, increases GLP-1 secretion from GLUTag cells (Kahles et al., 2014). LPS induces GLP-1 secretion to the same extent in both the fasted and fed state, where not surprisingly, insulin is only increased in these mice during the fed state. While these data demonstrate the glucose-dependency for the insulinotropic role of GLP-1, they also reveal nutrientindependent GLP-1R signaling pathways (Kahles et al., 2014). Plasma total GLP-1 concentrations are significantly higher in patients with sepsis than non-septic ICU patients; these levels are positively associated with IL-6, C-reactive protein, and the association of GLP-1 with plasma insulin is lost (Kahles et al., 2014). Taken together, this study reveals an integral role for the gut in systemic inflammation in pathways that remain incompletely understood.

Hwang et al. (2015) demonstrate that the antibiotics, vancomycin and bacitracin decrease the abundance of both Bacteroidetes and Firmicutes, and increase Proteobacteria, which is associated with increased GLP-1 secretion and improved glucose tolerance and insulin resistance. Coriobacteriaceae are involved in the metabolism of bile acids. This family of bacteria are able to metabolize primary bile acids into secondary bile acids, which then bind to TGR5 and stimulate GLP-1 secretion (Allin et al., 2015). Fourteen weeks of HFD-feeding 
supplemented with Akkermansia muciniphila significantly increases the ileal expression of $G c g$ and Pcsk1, and oral glucose-stimulated plasma GLP-1 compared to mice fed the HFD alone (Yoon et al., 2021). The cell-free supernatant from live A. muciniphila isolated from human feces significantly increases GLP-1 secretion from human enteroendocrine L cells (NCI-H716) in a dose-dependent manner and to a greater extent than the microbial products acetate and propionate (Yoon et al., 2021). Indeed, the authors identified, the protein P9 of the peptidase S41A family robustly increases GLP-1 secretion from human $\mathrm{L}$ cells in vitro and in mice after a single i.p. injection compared to saline control and injection of SCFA (Yoon et al., 2021). Mice fed a HFD supplemented with P9 display increased ileal Gcg and Pcsk1 expression as well as compared to mice fed the HFD-alone (Yoon et al., 2021). HFD-fed mice supplemented with A. muciniphila also display increased ileal and colonic Il-6 mRNA expression, and while IL-6 treatment in GLUTag cells does not stimulate GLP-1 secretion to the same extent as P9, co-treatment of IL-6 and P9 induces an additive effect (Yoon et al., 2021). Interestingly, P9 supplementation to a HFD does not increase plasma GLP-1 in $I l 6^{-/-}$mice (Yoon et al., 2021). A far lesser amount of studies have correlated populations of microbiota with GLP-2 secretion (Utzschneider et al., 2016). Already known to increase GLP-1 secretion, ingestion of Lactobacillus reuteri demonstrates increased GLP-2 secretion as well (Simon et al., 2015).

\section{Exercise-Induced GLP-1 Secretion}

Ninety minutes of exercise in mice induces a 2.5 -fold increase in plasma active GLP-1, mediated by skeletal-muscle-derived IL-6, as shown by abolishing exercise-induced active GLP-1 levels in $I l 6^{-/-}$mice and by treating wild-type mice with an antibody to IL-6 (Ellingsgaard et al., 2011). Interestingly, injecting mice with $400 \mathrm{ng}$ of recombinant mouse IL-6 twice daily for 7 days significantly increases fasting plasma active GLP-1, as well as ileal Gcg and Pcsk1 mRNA, but not plasma GLP-2 (ELISA) or DPP4 activity (Ellingsgaard et al., 2011). Indeed, GLUTag cells express the IL- 6 receptor, and IL- 6 treatment increases GLP- 1 secretion in a dose-dependent manner, where acute IL- 6 treatment increases GLP-1 exocytosis in a JAK2-STAT3-dependent manner, and chronic IL-6 treatment increases GLP-1 content and glucose uptake in a sodium glucose transporter 1-dependent manner in the L cell (Ellingsgaard et al., 2011). Surprisingly, despite increasing Gcg mRNA, chronic IL-6 treatment does not increase plasma GLP-2 levels suggesting a difference in GLP-1 and GLP-2 transcript or protein stability.

\section{RECEPTOR EXPRESSION WITHIN THE GASTROINTESTINAL TRACT}

GPCRs initiate the cellular responses to nearly all hormones and neurotransmitters; they are grouped into six main classes (A to F) by sequence homology and function. GCPRs have 7 transmembrane helices, and in the cases of GIPR, GLP-1R and GLP-2R, signal via Gs-mediated cAMP production and downstream signaling cascades. They are all class B1 GPCRs, share significant sequence similarity (Usdin et al., 1993) and form secretin-VIP receptor family (Campbell and Scanes, 1992).

\section{GIPR Expression}

The human GIP receptor (GIPR) gene is $\sim 13.8 \mathrm{~kb}$ long containing 14 exons. The receptor is 466 amino acids in length, including a signal peptide and 7 transmembrane domains; the gene contains 14 exons (Yamada et al., 1995). The first 92 bp of the GIPR gene contains $88 \%$ sequence identity between rat and human; interestingly, neither promoter regions contains a TATA box (Boylan et al., 2006). MZF1/Sp1-C (-75), Sp1-B $(-57)$, and Sp1-A $(-45)$ transcription factor binding sites were identified using radiolabeled synthetic probes and confirmed with CHiP analysis (Boylan et al., 2006). Indeed, sequence deletion between -85 and -40 decreases promoter activity by $88 \%$ (Boylan et al., 2006).

The identification of cell-specific expression of Gipr in the gastrointestinal tract remains largely unsolved; however, clues are beginning to emerge. On a whole tissue level, Gipr mRNA is expressed in rat stomach, duodenum, and proximal small intestine (Usdin et al., 1993; Coon et al., 2013). GIPR mRNA expression is detected in neuroendocrine tumors isolated from the small bowel and colorectal tumors (Sherman et al., 2013; Koehler et al., 2015) (Table 1). GIPR is faintly detected at the protein level at multiple sizes $(50,55,60$, and $70 \mathrm{kDa})$ in jejunal mucosal cells compared to the strong signal at $50 \mathrm{kDa}$ in pancreatic homogenates (Coon et al., 2013). In this same study, GIPR immunohistochemistry demonstrated positive staining beneath the basolateral surface of epithelial cells of the proximal jejunum (Coon et al., 2013). In the stomach, RNAseq of purified gastric somatostatin-producing D-cells from SST-Cre.ROSA26 $6^{\mathrm{EYFP}}$ mice reveal Gipr expression in these cells (Adriaenssens et al., 2015). A number of distinct neuronal populations also express the Gipr (Adriaenssens et al., 2019). Genetic elimination of Gipr in hematopoietic cell lineages, including endothelial cells (Gipr ${ }^{\text {Tie2- } /-}$ mice) does not impact jejunal Gipr mRNA (Pujadas et al., 2020).

\section{GLP-1R Expression in the Gut}

The transcriptional start site of the GLP-1R does not contain a TATA- or a CAAT-box element, however, it contains 3 putative Sp1 binding sites (Lankat-Buttgereit and Goke, 1997). Within the 350 bp region, $74 \%$ of the sequence is GC nucleotides (LankatButtgereit and Goke, 1997). Glp1r expression determined by RNAscope in situ hybridization reveals the highest expression in duodenal Brunner's glands and in stomach gland parietal cells (Wismann et al., 2017). Consistent with this use of a reporter mouse together with a number of validation approaches the GLP-1R was identified in chief cells, parietal cells and Brunner's glands (Andersen et al., 2021). A well-validated antibody to the GLP-1R (MAb 3F52) and corroborated with ${ }^{125}$ I-labeled GLP1 also demonstrated a strong signal in stomach parietal cells, basolateral epithelial cells in the duodenum, Brunner's glands and the myenteric nerve plexus (Pyke et al., 2014). Glp1r expression localizes to the basolateral side of enterocytes in the mucosal layer, and its abundance increases distally (Wismann et al., 2017). Glp1r mRNA is higher in mucosal cells from the ileum 
TABLE 1 | Summary of methods used to identify GIPR expressing cells within the gastrointestinal tract.

\begin{tabular}{|c|c|c|c|}
\hline Cell/organ & Species & Method of identification & References \\
\hline Small bowel neuroendocrine tumors & Human & GIPR mRNA qRT-PCR analysis & Sherman et al., 2013 \\
\hline Human colorectal tumors & Human & GIPR mRNA qRT-PCR analysis & Koehler et al., 2015 \\
\hline Human hypothalamic cells (vascular, glial, neuronal cells) & Human & Single-cell RNA sequencing of GIPR+ cells & Adriaenssens et al., 2019 \\
\hline T-cells, myeloid cells, myeloid precursors & Mouse & Gipr mRNA RT-qRT-PCR analysis & Pujadas et al., 2020 \\
\hline
\end{tabular}

and colon than in the non-epithelial fraction (Kedees et al., 2013). Conversely, Glp1r mRNA expression is highest in the jejunum within the epithelial fraction, followed by ileum then colon (Kedees et al., 2013). Glp1r is not detected in GLP-1+ cells (L cells) (Grigoryan et al., 2012); however, it is detected in chromogranin A+ enteroendocrine cells (Kedees et al., 2013; Andersen et al., 2021). Glp1r is also detected in Paneth cells, identified by lysozyme expression, in the jejunum and ileum crypts but not colon, distinct from proliferating Ki67+ cells (Kedees et al., 2013). Glp1r mRNA expression increases with age from 2 to 12 weeks in murine jejunum, ileum, and colon (Campos et al., 1994). Additionally, Glp1r expression in mice is detected in a subset of neurons of the myenteric and submucosal plexus (Andersen et al., 2021) that also express the neuron cytoplasmic protein 9.5 (PGP9.5) (Kedees et al., 2013) (Table 2 and Figure 1).

Studies using the mouse Glp1r promoter to drive expression of a fluorescent reporter protein reveal Glp1r expression in the antral area of the stomach (near the gastric pylorus) as a fibrous signal that does not overlap with smooth muscle $\alpha$-actin ( $\alpha$ SMA) (Richards et al., 2014). Glp1r expression is also observed in the arteries and arterioles of the intestine and colocalizes with $\alpha$ SMA and the pericyte marker NG2 (Richards et al., 2014) (Figure 1). In this model, Glp1r fluorescence is absent from the epithelial layer. Instead, mRNA expression is detected in myenteric ganglia in the intestinal mucosa, which are excitable by GLP-1 treatment ex vivo (64\% synaptic and 36\% after-hyperpolarizing types) (Figure 1 and Table 2). Indeed, 63\% of Glp1r-fluorescent neurons in primary small intestinal cultures and $19 \%$ in colonic cultures are neuronal nitric oxide synthase (nNOS) positive markers for inhibitory motor neurons (Richards et al., 2014). GLP-1 receptors are expressed in the enteric nervous system and in the vagus nerve (Grasset et al., 2017), which allow for the activation of the gut-brain-periphery axis. As such, the presence of GLP-1R + cell bodies in the enteric nervous system has been proposed to provide the signaling route to the central nervous system (CNS) required for distally secreted GLP-1. Consistent with Glp1r mRNA expression, immunofluorescence analyses in Glp1r.tdTomato reporter mice reveal GLP-1R expression in various enteroendocrine cells (Table 1), but not GLP-1+ cells (Andersen et al., 2021). Sequential collagenase digestion of the gut reveals Glp1r expression to be within the epithelial fraction instead of crypt, mesenchyme, or smooth muscle layer fractions (Yusta et al., 2015). Within the epithelial compartment of the small intestine, intraepithelial lymphocytes (IELs) (both the T $\alpha \beta$ and $\mathrm{T} \gamma \delta$ subsets) express Glp1r (Yusta et al., 2015; He et al., 2019) (Figure 1 and Table 2). Additionally, GLP-1R-expressing $\alpha \beta$ and $\gamma \delta \mathrm{T}$ cells transit to the gut via integrin B7 (Itgb7) (He et al., 2019). Indeed, IELs encode a functional GLP-1R as exendin-4 treatment in sorted activated and non-activated IELs increases cAMP levels. However, GLP-1R in IELs is not required for IEL development or recruitment to the gut as their abundance does not change in response to GLP-1R agonist treatment or in Glp1r $r^{-/}$mice (Yusta et al., 2015). These receptors are functional as mice receiving exendin- 4 i.v. exhibit an $84 \%$ increase in $c$-fos mRNA expression in the ileal mucosa (Kedees et al., 2013). The increased c-fos expression occurs in neurons as it is abolished upon co-treatment with tetrodotoxin, a voltage-gated sodium current blocker. Additionally, exendin-4 treatment increases $c$ fos expression in in GLP-1R+ Paneth cells (Figure 1), which is abolished when exendin-(9-39) is administered prior to exendin4 treatment (Kedees et al., 2013).

\section{GLP-2R Expression in the Gut}

The human GLP-2 receptor is localized to chromosome 17p13.3 and encodes a 550 amino acid $G$ protein-coupled receptor, processed to become a 486 amino acid receptor (Munroe et al., 1999). The gene at chromosome 17p13.3 encoding for the human GLP-2 receptor is also very well conserved as the rat sequence is $80 \%$ of the same amino acid sequence (Shin et al., 2005). The GLP-2 receptor is 14 exons long and has seven transmembrane domains and, although similar in amino acid sequence to both the glucagon and GLP-1 receptor, only recognizes GLP-2 and not related members of the glucagon family (Drucker and Yusta, 2014).

GLP-2R is expressed in the gastric mucosa in a subpopulation of fundas gland cells (Li et al., 2017) (Table 3). In the rat jejunum, Glp $2 r$ expression as a percentage of the expression in intact intestine is $0.07,33,256$, and $392 \%$ in the epithelium, mucosa, smooth muscle layer, and the intestine devoid of epithelium, respectively (Pedersen et al., 2015). GLP-2R transcripts are expressed in human colorectal tumors (Koehler et al., 2015) and GLP-2R protein is expressed in human colon neoplasms (Koehler et al., 2008) (Table 3). In rats, mice, marmosets and human intestinal tissue, GLP-2R localizes to cells residing immediately below the basolateral membrane of enterocytes, which are subepithelial myofibroblasts as marked by $\alpha \mathrm{SMA}$ (Orskov et al., 2005) (Figure 1 and Table 3). Glp2r expression is most abundant in the lamina propria of duodenal and jejunal villi (Wismann et al., 2017), where in the jejunum its expression within the lamina propria stromal cells predominate in the upper half of villi (Yusta et al., 2019) (Figure 1). The receptor's location in the lamina propria is consistent with evidence that suggests the link between GLP-2 to KGF, IGF-1, and ErbB, as these growth factors are produced and secreted from stromal cells found in the lamina propria (Yusta et al., 2019). GLP$2 \mathrm{R}$ protein in neonatal pigs colocalizes with chromogranin $\mathrm{A}+$ 
TABLE 2 | Summary of methods used to identify GLP-1R expressing cells within the gastrointestinal tract.

\begin{tabular}{|c|c|c|c|}
\hline Cell/organ & Species & Method of identification & References \\
\hline Human colorectal tumors & Human & GLP-1R expression (qRT-PCR analysis of RNA). & Koehler et al., 2015 \\
\hline $\begin{array}{l}\text { Intestinal intraepithelial } \\
\text { lymphocyte (IEL) }\end{array}$ & Mouse & $\begin{array}{l}\text { Glp-1r Real-time qRT-PCR (mRNA), immunohistochemistry (rabbit } \\
\text { polyclonal anti-CD3 antibody and hematoxylin). } \\
\text { Used GLP-1R-1- model. } \\
\text { G/p-1r transcript identified in isolated RNA (qRT-PCR), southern blot } \\
\text { detects Glp-1r PCR product. }\end{array}$ & Yusta et al., 2015 \\
\hline Synaptic type neurons & Mouse & $\begin{array}{l}\text { GLP-1R fluorescent cell population. } \\
\text { Whole cell current clamp. }\end{array}$ & Richards et al., 2014 \\
\hline $\begin{array}{l}\text { After-hyperpolarizing type } \\
\text { neurons }\end{array}$ & Mouse & $\begin{array}{l}\text { GLP-1R fluorescent cell population. } \\
\text { Whole cell current clamp. }\end{array}$ & Richards et al., 2014 \\
\hline Inhibitory motor neurons & Mouse & $\begin{array}{l}\text { Immunostained for nNOS (marker mainly restricted to inhibitory } \\
\text { motor neurons), most GLP-1R fluorescent neurons were nNOS+. }\end{array}$ & Richards et al., 2014 \\
\hline $\begin{array}{l}\text { Intrinsic primary afferent } \\
\text { neurons }\end{array}$ & Mouse & $\begin{array}{l}\text { GLP-1R-fluorescent cells in culture stained for Calretinin (marker for } \\
\text { intrinsic primary afferent neurons) }\end{array}$ & Richards et al., 2014 \\
\hline Vagal afferent neurons & Mouse & $\begin{array}{l}\text { GLP-1R-fluorescent cells. } \\
\text { Immunostained for RFP. }\end{array}$ & Richards et al., 2014 \\
\hline Intraepithelial lymphocytes & Mouse & $\begin{array}{l}\text { Glp1r.tdTomato reporter mouse. } \\
\text { ISH of GLP-1R and tdTomato expression. } \\
\text { Glp-1r mRNA in situ hybridization. }\end{array}$ & Andersen et al., 2021 \\
\hline $\begin{array}{l}\text { Neurotensin+ N-cells, } \\
\text { Somatostatin+ D-cells, } \\
\text { PYY+ L-cells, serotonin+ } \\
\text { enterochromaffin cells (EC) }\end{array}$ & Mouse & $\begin{array}{l}\text { Glp1r.tdTomato reporter mouse. } \\
\text { ISH of GLP-1R and tdTomato expression. } \\
\text { Glp-1r mRNA in situ hybridization. }\end{array}$ & Andersen et al., 2021 \\
\hline Mucus cells (antrum) & Mouse & $\begin{array}{l}\text { Glp1r.tdTomato reporter mouse. } \\
\text { ISH of GLP-1R and tdTomato expression. } \\
\text { Glp-1r mRNA in situ hybridization. }\end{array}$ & Andersen et al., 2021 \\
\hline Parietal cells & Mouse & $\begin{array}{l}\text { Td.Tomato-positive cells. } \\
\text { ISH of GLP-1R and tdTomato expression. } \\
\text { Glp-1r mRNA in situ hybridization. }\end{array}$ & Andersen et al., 2021 \\
\hline Chief cells & Mouse & $\begin{array}{l}\text { Td.Tomato-positive cells. } \\
\text { Immunohistochemistry. }\end{array}$ & Andersen et al., 2021 \\
\hline$\alpha \beta, \gamma \delta$ T cells & Mouse & Expression of Glp-1r (mRNA). & He et al., 2019 \\
\hline Myenteric neurons & Mouse & Glp1r-CRE fluorescent reporter. & Richards et al., 2014 \\
\hline $\begin{array}{l}\text { Neurons of the myenteric } \\
\text { and submucosal plexus }\end{array}$ & Mouse & $\begin{array}{l}\text { Expression of Glp-1r (mRNA). } \\
\text { Immunohistochemistry. }\end{array}$ & Kedees et al., 2013 \\
\hline Brunner's gland (duo) & Mouse & $\begin{array}{l}\text { Glp-1r.tdTomato signal. } \\
\text { ISH of GLP-1R and tdTomato expression. } \\
\text { Glp-1r mRNA in situ hybridization. }\end{array}$ & Andersen et al., 2021 \\
\hline $\begin{array}{l}\text { Parietal cells } \\
\text { Brunner's gland }\end{array}$ & Monkey & MAb 3F52. & Pyke et al., 2014 \\
\hline $\begin{array}{l}\text { Parietal cells } \\
\text { Brunner's glands }\end{array}$ & Mouse & RNAScope in situ hybridization. & Wismann et al., 2017 \\
\hline Myenteric nurons & Monkey & MAb 3F52 & Pyke et al., 2014 \\
\hline Epithelial cells & Mouse & $\begin{array}{l}\text { Expression of Glp-1r (mRNA). } \\
\text { Immunohistochemistry. }\end{array}$ & Kedees et al., 2013 \\
\hline Basolateral epithelial cells & Monkey & MAb 3F52. & Pyke et al., 2014 \\
\hline
\end{tabular}

enteroendocrine cells in the jejunal villus $(\sim 58 \%)$ and crypt epithelium (60\%) (Guan et al., 2006) (Table 3). A rat polyclonal antibody localized using immunohistochemistry the GLP-2R to vagal afferents, enteric neurons, enteroendocrine cells, and myenteric plexus nerve fibrils (Nelson et al., 2007). Isolated rat intestinal mucosal cells expressing Glp2r transcripts also expressed markers for enteroendocrine or neural cells (Walsh et al., 2003) (Table 3). Isolated Human GLP-2R protein also colocalizes to chromogranin A+ enteroendocrine cells in both the villus and crypt epithelium (Guan et al., 2006). Human GLP$2 \mathrm{R}$ protein colocalizes to 5 -HT-containing cells in the epithelium, a neurotransmitter released by enteroendocrine cells (Guan et al., 2006). Human VIP+ enteric neurons in the submucosal plexus and myenteric plexus express the GLP-2R (Guan et al., 2006) (Table 3). In the mouse duodenal myenteric plexus, $\sim 18 \%$ of GLP-2R+ are nNOS+, $10 \%$ are vasoactive intestinal polypeptide 
(VIP)+, $\sim 71 \%$ are choline-acetyltransferase (ChAT)+, and 27\% are SP+ (Cinci et al., 2011) (Figure $\mathbf{1}$ and Table 3). In the submucosal plexus, only SP+ cells were GLP-2R+ (Cinci et al., 2011) (Figure 1 and Table 3). Human eNOS+ enteric neurons in the submucosa also express the GLP-2R, supporting a direct role for GLP-2-mediated increase in eNOS protein and NOS release through cAMP-dependent protein kinase A (Guan et al., 2006) (Table 3).

\section{DISTINCT AND OVERLAPPING FUNCTIONAL ROLES OF GIPR, GLP-1R, AND GLP-2R}

\section{Regulation of Post-prandial Lipid Metabolism}

Spearman correlations between GLP-1, GLP-2, GIP, and TG responses in plasma during an oral fat tolerance test in obese men reveal a small albeit significant positive correlation ( $r$-squared values close to zero) between all three hormone area under curves (AUCs) for TG and apoB48 (Matikainen et al., 2016). In this study, these gut hormones display small contributions to explaining the variance in TG AUC, where instead fasting TG values serve as the largest contributor for explaining this variance (Matikainen et al., 2016). Still, the high concentrations of GLP-1, GLP-2, and GIP within the gut circulation relative to systemic circulation suggest that endogenous gut hormone action on chylomicron secretion may be local and underestimated.

\section{GIP Receptor (GIPR)}

Chronic reduction in GIP secretion reduces obesity and insulin resistance in high-fat fed mice (Nasteska et al., 2014). Interestingly, dietary fat absorption and intestinal-TG secretion are unchanged upon $\mathrm{K}$ cell destruction (Pedersen et al., 2013; Holst et al., 2016). Similarly, GIP infusion i.v. does not impact TG levels (Holst et al., 2016). Rather, GIP has been shown to increase circulating lipid clearance via an increase in adipose tissue blood flow. GIPR antagonist, GIP(3-30)NH2, and GIP co-infusion in lean individuals prevented a fivefold increase in adipose tissue blood flow induced by GIP infusion alone (Asmar et al., 2017). Additionally, both TG and glucose uptake decrease in response to GIP(3-30)NH2 alone and GIP co-infusion compared to GIP infusion alone (Asmar et al., 2017).

Co-administration of triton-WR1339 infusion and D-Ala2GIP injection 20 min following oil gavage in mice significantly increases TG accumulation in plasma at 60 and $90 \mathrm{~min}$, and ApoB-48 levels at 90 min compared to PBS control (Hsieh et al., 2010), suggesting a role for GIP in plasma TG independent of triglyceride rich lipoprotein (TRL) clearance. Additionally, selective deletion of Gipr in brown adipose tissue significantly increases both fasting (overnight) and fed (1h re-feed) TG levels of high-fat fed mice (Beaudry et al., 2019). Furthermore, acute lipid challenges in Gipr ${ }^{B A T-/-}$ mice fed a high-fat diet for 8-10 weeks housed at room temperature reveal significantly increased TG excursion, an effect lost upon 28 weeks of highfat feeding (Beaudry et al., 2019). GIP, in the presence of insulin, increases LPL gene expression in 3T3-L1 adipocytes via PKB/LKB1/AMPK signaling (Kim et al., 2007a) mediated by resistin (Kim et al., 2007b) and in human adipocytes by increasing TORC2 and phospho-CREB nuclear localization to bind to the CRE-II promoter region (Kim et al., 2010). GIP infusion significantly increases LPL activity in obese ( $f a / f a)$ and lean $(f a /-)$ VDF Zucker rats (Kim et al., 2007a). Conversely, treatment of rats with the GIPR antagonist, rat GIP (3-30)NH2, does not modify food intake but significantly increases plasma TG and LPL compared with controls (Baldassano et al., 2019). Alternatively, D-Ala2-GIP treatment significantly reduces serum LPL activity in both chow- and high-fat diet-fed mice (Szalowska et al., 2011). However, the significance of endogenous GIP secretion as a dominant regulator of LPL secretion is uncertain. In humans, intravenous infusion of a somatostatin analog, octreotide, $30 \mathrm{~min}$ prior to carbohydrate meal (Hycal) significantly impairs insulin, GLP-1, and GIP secretion in both lean and obese women, yet post-heparin LPL activity (contributions from adipose, skeletal and cardiac tissue) is unchanged $1.5 \mathrm{~h}$ post-peak insulin in lean and obese women (Ranganath et al., 1999). Therefore, suppression of insulin, GIP, and GLP-1 does not impact plasma LPL activity following oral carbohydrate.

\section{GLP-1R}

High-fructose feeding for 10 days in hamsters significantly increases plasma TG and cholesterol levels (Hsieh et al., 2010), where only the former can be significantly decreased after 3 weeks of systemic DPP4 inhibition (sitagliptin). This treatment paradigm reduces post-prandial TRL-fraction TG levels and ApoB48 production (Hsieh et al., 2010). Acute sitagliptin administration to chow-fed mice significantly reduces plasma cholesterol and TG at $90 \mathrm{~min}$ post-triton infusion and oil gavage (Hsieh et al., 2010). Co-administration of triton by infusion and exendin- 4 by injection 20 min following oil gavage in mice significantly decreases TRL-fraction TG accumulation at $90 \mathrm{~min}$, and ApoB48 levels at 60 and $90 \mathrm{~min}$, an effect significantly reversed by the co-administration of GLP-1R antagonist exendin(9-39) 20 min prior to gavage (Hsieh et al., 2010). While sitagliptin and exendin-4 significantly increase plasma insulin levels 5-min post injection, these levels are not significantly different from PBS control after 20 min, suggesting that the GLP-1 mediated reduction in intestinal-TG secretion is independent of the incretin effect. Indeed, the authors show that in co-administration of insulin injection and triton infusion 20 min post-olive oil gavage in mice does not significantly change the accumulation of TG in plasma (Hsieh et al., 2010). This effect is significant given the studies in humans where acute insulin treatment inhibits intestinal lipoprotein secretion in response to hourly meals, an effect partially lost upon concomitant Intralipid and heparin infusion (Pavlic et al., 2010), suggesting mediation by FFA. Exendin-4 decreases TG and cholesterol in the VLDL/chylomicron fraction of chow-fed hamsters while a GLP-1R antagonist increases ApoB48 accumulation 120 minpost oil in chow-fed hamsters (Hsieh et al., 2010). Despite similar gastric emptying rates between $G l p 1 r^{-/-}$mice wild-type controls (Baggio et al., 2004), Glp1r ${ }^{-/-}$mice display significantly increased TG accumulation in plasma and the TRL fraction 
TABLE 3 | Summary of methods used to identify GLP-2R expression throughout the gastrointestinal tract.

\begin{tabular}{|c|c|c|c|}
\hline Cell/organ & Species & Method of identification & References \\
\hline Human colorectal tumors & Human & GLP-2R mRNA transcripts expressed qRT-PCR. & Koehler et al., 2015 \\
\hline Human colon neoplasms & Human & Immunohistochemistry. & Koehler et al., 2008 \\
\hline Gastric chief cells & Human & $\begin{array}{l}\text { GLP-2R Fluorescence ISH. } \\
\text { GLP-2R by western blot. }\end{array}$ & Li et al., 2017 \\
\hline Myenteric plexus & Human & In vitro receptor autoradiography of human intestinal tissue. & Pedersen et al., 2015 \\
\hline Lamina propria stromal cells & Mouse & $\begin{array}{l}\text { ISH with RNAscope, Glp-2r mRNA detected. } \\
\text { GLP2R-driven LacZ expression. }\end{array}$ & Yusta et al., 2019 \\
\hline Vagal afferents & Rat & $\begin{array}{l}\text { GLP-2R antibody localizing GLP-2R immunoreactivity. } \\
\qquad \mathrm{ISH} .\end{array}$ & Nelson et al., 2007 \\
\hline Intestinal muscularis & Mouse & Glp-2r mRNA transcripts by RT-PCR. & Shin et al., 2005 \\
\hline Jejunal enteroendocrine cells & Pig & $\begin{array}{c}\text { Glp-2r mRNA transcripts by qRT-PCR of laser micro-dissected } \\
\text { tissue. } \\
\text { In situ hybridization. } \\
\text { Immunostaining. }\end{array}$ & Guan et al., 2006 \\
\hline Subepithelial myofibroblasts & MouseRatMouse & $\begin{array}{l}\text { Glp-2r mRNA expression by qRT-PCR. } \\
\text { Immunohistochemistry (antibody 99077). }\end{array}$ & Orskov et al., 2005 \\
\hline Subepithelial myofibroblasts & MouseRatMouse & $\begin{array}{l}\text { Glp-2r mRNA expression by qRT-PCR. } \\
\text { Immunohistochemistry (antibody 99077). }\end{array}$ & Orskov et al., 2005 \\
\hline Isolated intestinal mucosal cells & Rat & GLP-2R mRNA transcripts by RT-PCR. & Walsh et al., 2003 \\
\hline $\begin{array}{l}\text { Lamina propria of duodenal and } \\
\text { jejunal villi, submucosal nerve } \\
\text { plexuses }\end{array}$ & Mouse & RNAScope in situ hybridization. & Wismann et al., 2017 \\
\hline $\begin{array}{l}\text { Smooth muscle layer, intestine } \\
\text { devoid of epithelium, respectively }\end{array}$ & Rat & Glp-2r mRNA expression by qRT-PCR. & Pedersen et al., 2015 \\
\hline
\end{tabular}

as well as TRL ApoB48 post-oil gavage (Hsieh et al., 2010). Furthermore, pulse-chase experiments in primary suspended villi from chow-fed hamsters reveal that exendin-4 does not change cellular ApoB48 levels, but significantly decreases ${ }^{35} \mathrm{~S}$-labeled ApoB48 secretion in the media (Hsieh et al., 2010).

Patients with type 2 diabetes treated with metformin and the GLP-1R agonist exenatide for 1 year display significantly reduced circulating TG, apoB48, and FFA following an early meal (50 $\mathrm{g}$ of fat, $75 \mathrm{~g}$ of carbohydrates, $35 \mathrm{~g}$ of protein). Interestingly, TG and apoB48 levels rapidly rise in the $2 \mathrm{~h}$ following the second meal in these patients to levels similar as pre-treatment responses (Bunck et al., 2010). In patients with recent-onset type 2 diabetes, subcutaneous injection of exenatide immediately prior to meal consumption $(5,384 \mathrm{~kJ})$ significantly reduces serum insulin at $2,4,6$, and $8 \mathrm{~h}$ postmeal (Schwartz et al., 2010). Moreover, exenatide reduces postmeal serum TG and remnant lipoprotein TG at 2-, 4-, and 6-h post-meal, in particular preventing the 4 -h peak in TG seen in placebo controls (Schwartz et al., 2010). Plasma remnant lipoprotein cholesterol is also significantly reduced $4 \mathrm{~h}$ postmeal in these patients (Schwartz et al., 2010). Similarly, exenatide significantly reduces serum apoB48 levels throughout the 8-h sampling period (Schwartz et al., 2010). Meal-induced increases in plasma apoCIII are also prevented by exenatide (Schwartz et al., 2010). Two weeks of exenatide treatment twice daily, $1 \mathrm{~h}$ before morning and evening meals, significantly reduces plasma TG following these meals ( $\sim 50 \%$ carbohydrate, $20 \%$ protein, and $30 \%$ fat) compared to placebo but TG levels rise to similar levels as placebo following the midday meal, where no changes in post-prandial FFA concentrations are observed (Schwartz et al., 2008). Exenatide treatment and co-infusion of d3-leucine $5 \mathrm{~h}$ after starting continuous infusion of lipid/carbohydrate formula in healthy fasted humans via nasoduodenal tube $2 \mathrm{~h}$ after starting a pancreatic clamp does not significantly affect plasma TG, FFA, or TRL-TG compared to placebo (Xiao et al., 2012). However, this treatment paradigm demonstrates the acute reduction in apoB48 concentrations in the TRL fraction for $10 \mathrm{~h}$ post-injection $(-37 \%)$ compared to placebo controls with a significant decrease in apoB48 production rate, no change in fractional catabolic rate, and no changes in hepatic apoB100 levels were observed (Xiao et al., 2012). Still, the precise mechanisms through which GLP-1R signaling controls post-prandial lipid metabolism remain unclear.

Genetic elimination of $\operatorname{Itg} b 7$ in mice decreases the expression of Glp1r on $\alpha \beta$ and $\gamma \delta$ T cells yet increases fasting plasma GLP1, intestinal $G c g$ mRNA expression, and ileal L cell abundance (He et al., 2019). Interestingly, these mice display improved lipid tolerance (He et al., 2019). In vitro experiments reveal GLP-1 concentration in media after $24 \mathrm{~h}$ of co-incubation of GLUTag cells with $\alpha \beta$ and $\gamma \delta$ T cells negatively associate with the level of Glp1r expression in the latter cells (He et al., 2019). Moreover, high Glp1r expressing $\alpha \beta$ and $\gamma \delta$ T cells can further decrease GLP-1 concentration in media from GLUTag cells in the presence of exendin-4, suggesting that Glp1r-expressing $\alpha \beta$ and $\gamma \delta \mathrm{T}$ cells act as a sink for local GLP-1 production (He et al., 2019). Additionally, this supports the increased circulating GLP-1 levels observed in Glp1r-/- mice (Lamont et al., 2012), albeit the intact receptor is required for improved post-prandial lipid tolerance. These results are replicated ex vivo, where media GLP-1 concentration from ileal tissue from $\operatorname{Itg} b 7^{-/-}$ 
mice is significantly higher than in the media from wildtype tissue, and this increase can be replicated in wild-type tissue upon GLP-1R antagonist (exendin-9) treatment (He et al., 2019). Overall, this additional pool of GLP-1 during fasting clearly plays an important role in GLP-1R-mediated control of circulating lipoproteins, suggesting that the circuit engaged occurs within the gut.

\section{GLP-2R}

Subcutaneous injection $(15,000 \mu \mathrm{g})$ of GLP-2 $5 \mathrm{~h}$ after the start of a liquid mixed macronutrient formula infusion through a nasoduodenal tube in healthy men significantly increases peak plasma TG and TRL-apoB48 at $1 \mathrm{~h}$ and area under the concentration curve for the first $3 \mathrm{~h}$ of treatment (Dash et al., 2014). GLP-2 does not increase TRL apoB48 by increasing the synthesis of new particles, nor does it decrease the clearance of TRL apoB48, rather, GLP-2 stimulates the release of pre-formed TRL apoB48 during the first hour of treatment (Dash et al., 2014). Similarly, GLP-2 treatment significantly increases plasma TG, TRL-TG, TRL retinyl palmitate, and retinyl palmitate in the chylomicron fraction for $2 \mathrm{~h}$ when administered $7 \mathrm{~h}$ after a meal containing retinyl palmitate (Dash et al., 2014).

Glp $2 r^{-/-}$mice display increased fasting and $10 \mathrm{~min}$ postolive oil gavage plasma active GLP-1 compared to wild-type controls, despite similar fasting DPP4 activity levels in circulation (Fuchs et al., 2020). Accordingly, plasma-TG excursion following the olive oil gavage is not significantly different from wild-type controls, although trends for decreased secretion are observed (Fuchs et al., 2020). When administered $20 \mathrm{~min}$ after the oil gavage, GLP-2 increases TRL-TG and TRL-cholesterol 3.5- and 3 -fold, respectively, in hamsters (Hsieh et al., 2009). Radiolabeled gavage experiments $\left({ }^{3} \mathrm{H}\right.$-triolein) reveal that GLP-2 increases the radiolabel incorporation into plasma TG at 60- and 90-min post-gavage with no differences observed in plasma cholesterol compared to control (Hsieh et al., 2009). Similar to hamsters, GLP-2 treatment significantly increases plasma TG concentration at 60- and 90-min post-oil gavage as well as TG and apoB48 accumulation in the chylomicron fraction of plasma in the presence of triton WR-1339 (blocking lipoprotein catabolism) (Hsieh et al., 2009). GLP-2 does not increase the protein expression of FATP4 or MTP, rather it significantly increases the expression of glycosylated CD36. CD36 localizes to the apical membrane of enterocytes found on the tips of jejunal villi (Hsieh et al., 2009). Assessing the requirement of CD36 for GLP-2mediated increases in intestinal-TG secretion are complicated by the increased fatty acid absorption (as shown by appearance of radiolabel in plasma), TRL-TG and TRL-apoB48 secreted by $C d 36^{-/-}$mice compared to wild-type controls (Hsieh et al., 2009). Still, GLP-2 does not increase TRL-TG or TRL-apoB48 secretion in $\mathrm{Cd} 36^{-/-}$mice compared to saline control (Hsieh et al., 2009). ${ }^{35}$ S-methionine pulse-chase experiments of jejunal fragments isolated hamsters $1 \mathrm{~h}$ after an olive oil gavage reveal that GLP-2 treatment ex vivo increases the secretion of the radiolabelled-apoB48 into the media with unchanged cellular concentrations. However, since the GLP-2 treatment ex vivo was for $45 \mathrm{~min}$ (Hsieh et al., 2009), and that GLP-2 treatment rapidly induces the mobilization of pre-formed chylomicrons by $1 \mathrm{~h}$ treatment in humans (Dash et al., 2014), this increase in apoB48 synthesis may be driven by clearing the preformed particles earlier than vehicle controls. Still, this experiment demonstrates that GLP-2R-expressing cell(s) mediating this indirect increase reside near enterocytes in these jejunal fragments. As previously mentioned, GLP-2 increases intestinal blood flow and stimulates the expression of intestinal endothelial nitric oxide synthase (eNOS) (Guan et al., 2003). Inhibiting nitric oxide synthase with L-NAME does not impact intestinal-TRL secretion in hamsters (Hsieh et al., 2015), likely due to the lymphatic fate of these particles. Still, preventing GLP-2-mediated increases in portal and intestinal blood flow via L-NAME, blocks the GLP-2-mediated increase in apoB48 in the TRL fraction of plasma (Hsieh et al., 2015). Mice lacking endothelial nitric oxide synthase $\left(e N O S^{-/-}\right.$mice) display normal radiolabel appearance into plasma as wild-type controls, however, GLP-2 treatment in these mice did not increase plasma ${ }^{3} \mathrm{H}$ compared to treatment in wild-type mice (Hsieh et al., 2015). ApoB48 in the TRL fraction is significantly lower in $e \mathrm{NOS}^{-/-}$mice compared to wild-type mice, independent of GLP-2 treatment (Hsieh et al., 2015). Additionally, jejunal TG mass is significantly greater in $e \mathrm{NOS}^{-/-}$mice compared to wild-type mice, again independent of GLP-2, suggesting that eNOS is involved in the release of stored TG as large chylomicrons rather than absorbed dietary TG and this is upregulated by exogenous GLP-2 (Hsieh et al., 2015). Indeed, GLP-2 treatment $5 \mathrm{~h}$ after $200 \mu \mathrm{L}$ of intraduodenally administered olive oil significantly increases TRL-TG, which is inhibited by co-treatment with L-NAME. Similar to acute L-NAME treatment, L-NAME treatment alone $5 \mathrm{~h}$ post-oil does not change TRL-TG secretion compared to saline control (Hsieh et al., 2015), suggesting that GLP-2 may influence the partitioning of dietary fatty acids from lymph to portal circulation or that endogenous gut-hormone action by GLP-1R and/or GIPR maintains normal intestinal-TRL secretion. GLP2 rapidly increases lymph flow and cumulative lymph volume in cannulated rats $300 \mathrm{~min}$ after an intraduodenal bolus of Intralipid 20\% (Stahel et al., 2019). GLP-2 does not significantly change lymph TG concentration, TG output (mL TG per hour) or chylomicron size (TG:apoB48) compared to placebo control, rather it increases the cumulative increase in lymph TG in $60 \mathrm{~min}$ (Stahel et al., 2019).

\section{Regulation of Intestinal Growth and Response Injury GLP-1R}

Interestingly, Gcgr-/- mice have increased circulating GLP-1 and GLP-2 (Gelling et al., 2003; Ali et al., 2011; Grigoryan et al., 2012). Unsurprisingly, Gcgr ${ }^{-/}$mice have significantly increased small and large intestinal length and weight due to the elevated levels of gut-derived hormones (Koehler et al., 2015). Consistent with this, co-administration of the GLP-2R agonist $\mathrm{h}\left(\mathrm{Gly}^{2}\right) \mathrm{GLP}$ 2 and exendin-4 increases small intestinal weight and length to a greater extent compared to the agonists administered alone (Koehler et al., 2015). However, using $G c g r^{-/-}: G l p 2 r^{-/-}$ mice, the authors demonstrate that GLP-1R signaling can still increase small intestinal length and weight compared to wild 
type, although not to the same extent as in $\mathrm{Ggr}^{-/}$mice (Koehler et al., 2015). However, despite these potent effects, increased large bowel weight and length in $\mathrm{Gcgr}^{-} /-$mice appears to be driven by GLP-1R signaling as these parameters are unchanged in $\mathrm{Gcgr}^{-/-}: G l p 2 r^{-/-}$mice (Koehler et al., 2015). Therefore, the trophic effects of GLP-1R signaling appear to target the distal gut (small intestinal length, large bowel length and weight) (Koehler et al., 2015). Indeed, exendin-4 and liraglutide treatment for 1 week increases small intestinal length and weight as well as large intestinal weight in wild-type mice but not in Glp1r ${ }^{-/-}$mice (Koehler et al., 2015). Glp1r ${ }^{-/-}$mice lose significantly more weight, exhibit significantly increased disease activity scores and greater colon damage than wild-type controls in response to DSS-induced colitis (Yusta et al., 2015). Unlike GLP-2, which increases crypt cell proliferation and villus elongation (Drucker and Yusta, 2014) exendin-4 treatment does not enhance crypt-cell proliferation, which was demonstrated by BrDU labeling and measuring crypt depth (Koehler et al., 2015). Instead, chronic treatment of exendin- 4 increases crypt number in the proximal intestine and colon, leading to increased intestinal circumference and length (Koehler et al., 2015). The authors demonstrate that GLP-1R agonist treatment induces expression of tyrosine kinase IGF1R/ErbB (EGFR) pathways, however, agonist treatment can still increase intestinal growth in the absence of intestinal epithelial IGF1 receptor as well as EGF receptor signaling (Koehler et al., 2015). Acute, but not chronic, exendin-4 treatment increases Fgf7 mRNA expression in the small intestine (Koehler et al., 2015). The intestinotrophic effects of exendin-4 are lost in $F g f 7^{-/-}$mice, effects that were not observed upon GLP-2 treatment in these mice (Koehler et al., 2015). Despite the role of IELs in mediating intestinal mucosal repair through Fgf7/KGF (Boismenu and Havran, 1994), reconstituting Glp1r+ IELs into Glp1r $r^{-/-}$mice via bone marrow transplant does not rescue the intestinotrophic effects of exendin4 in these mice (Koehler et al., 2015).

Plasma GLP-1 levels increase in response to intestinal injury or mucosal inflammation (Zietek and Rath, 2016). IELs protect the epithelial barrier by promoting pathogen clearance and lysing pathogen-infected cells (Cheroutre et al., 2011). Treatment with exendin-4 significantly attenuates proinflammatory cytokines IL-2, IL-17a, interferon $\gamma$, tumor necrosis factor- $\alpha$ mRNA and protein in IELs activated by immobilized anti-CD3 and soluble anti-CD28, an effect partially blocked by GLP$1 \mathrm{R}$ antagonist exendin (9-39) (Yusta et al., 2015). Colonic mRNA expression analysis in Glp1r ${ }^{-/-}$mice at baseline reveal significant reductions in trefoil factor (Tff-1 and -2), transforming growth factor (Tgf-b1 and Tgf-3), epidermal growth factor receptor (Egfr), keratinocyte growth factor ( Fgf7), hepatocyte growth factor $(\mathrm{Hg} f)$ (epithelial protection and repair), Il6, Illb (innate immune response), Il12b (inflammation) (Yusta et al., 2015). Upon dextrane sulfate (DS)-induced colitis, colonic Tff2, $T f f 3, T g f b 1$, and $T g f b 3$ mRNA levels are significantly lower in Glp1 $r^{-/-}$mice compared to wild-type controls (Yusta et al., 2015). By contrast, colonic Tgfb2 and Ifng mRNA levels are significantly higher in $G l p 1 r^{-/-}$mice compared to wild-type controls (Yusta et al., 2015). Genes involved in innate immunity and inflammation, which are lower in $G l p 1 r^{-/-}$at baseline, increases in both WT and Glp1r-/- in DSS-induced colitis, but differences between genotypes are lost (Yusta et al., 2015). Bone marrow transplantation, and therefore re-establishment of wildtype IELs in the intestinal mucosa, from wild-type donor mice to wild-type and Glp1r ${ }^{-/-}$recipient mice, normalizes colonic gene expression in response to DSS-induced colitis (Yusta et al., 2015). Exendin-4 increases mRNA expression of $I l 1 b, I l 6, I l 22, I l 12 b$, Tnfa, Ccl2, Cxcl1, and Cxcl2 (innate immunity), regenerating islet-derived protein 2, RegIIIy and RegIIIB (anti-microbial proteins), as well as $I l-5, I l-13$ (pathogen clearance) within $4 \mathrm{~h}$ of administration, returning to baseline expression by $24 \mathrm{~h}$ (Yusta et al., 2015), suggesting that GLP-1R activation engages a cytoprotective response. Exendin-4 treatment following DSSinduced colitis does not prevent weight loss, colon length shortening, or improve colon damage score, however, reductions in colon weight are attributable to a reduction of edema (Yusta et al., 2015).

\section{GLP-2R}

The intestinotrophic effects of GLP-2 have been well-described since its initial characterization (Drucker et al., 1997). GLP-2 increases intestinal cell proliferation while inhibiting apoptosis, leading to increased villus height and expanding the absorptive mucosal surface (Drucker et al., 1997). GLP-2 decreases mucosal injury by stimulating intestinal growth; specifically, increasing villus height, crypt depth, improving nutrient absorption and nutritional status (Estall and Drucker, 2005). Mice fasted for $24 \mathrm{~h}$ exhibit small intestinal atrophy, a decrease in intestinal weight, a decrease in crypt-villus height, and an increase in villus apoptosis (Shin et al., 2005). Refeeding restored all parameters, while co-administration of GLP-2R antagonist, GLP$2^{3-33}$, prevents adaptive changes to refeeding (Shin et al., 2005). Similarly, the restoration of jejunal mucosal mass, protein, and DNA $25-65 \%$ by ad libitum or intragastric infusion for 24 days is blunted with 2.5 or $50 \mu \mathrm{g} / \mathrm{kg}$ body weight GLP$2^{3-33}$, but not $10 \mu \mathrm{g} / \mathrm{kg}$ body weight GLP- $2^{3-33}$, compared to the baseline fed group (Nelson et al., 2008). Mucosal growth following refeeding is associated with increased circulating GLP2 and jejunal Igf- 1 mRNA expression. Interestingly, GLP-2 ${ }^{3-33}$ at any dose prevents restoration of plasma IGF-I levels in response to refeeding (Nelson et al., 2008). There is evidence for both paracrine and neuronal mechanisms for GLP-2mediated gut growth. GLP-2R+ myofibroblasts in the small intestine and colon contain keratinocyte growth factor (KGF), whereby immunoneutralization of KGF abolishes the trophic effects of GLP-2 treatment in the colon, but not the small intestine in mice (Orskov et al., 2005). Mechanistically, GLP-2 activates its receptors on subepithelial myofibroblasts, which in turn increase expression and secretion of IGF-1 (Dube et al., 2006). Gut growth coincides with increased IGF-1 and IGF-2, particularly in the mucosal and muscularis regions (Dube et al., 2006). GLP-2-mediated increases in IGF-1 activates the IGF-1 receptor on intestinal epithelial cells to stimulate proliferation (Rowland et al., 2011). Chronic GLP-2 treatment does not increase crypt-cell proliferation, and growth of the crypt-villus is reduced in intestinal epithelial-specific IGF knockout mice (Rowland et al., 2011). 
Treatment of mice with DS-induced colitis (resembling human ulcerative colitis) with the human GLP-2 analog $\mathrm{h}\left(\mathrm{Gly}^{2}\right) \mathrm{GLP}$, twice daily for 10 days, reverses weight loss independent on food intake, decreases interleukin-1 expression and increased colon length, crypt depth, and mucosal area compared to treatment with saline (Drucker et al., 1999). $\mathrm{h}\left(\mathrm{Gly}^{2}\right)$ GLP-2 treatment also improves survival in drug-induced enteritis (non-steroidal anti-inflammatory drug - indomethacin) survival, reduces disease activity, decreases occurrence of intestinal ulcerations, and lowers cytokines and myeloperoxidase activity in mice (Boushey et al., 1999). In Glp2r $r^{-1-}$ mice, levels of various Paneth cell genes are lower in the jejunum and ileum, some specifically in charge of defensin activity suggesting alterations in gut barrier function. The bacterial translocation and Paneth cell defect alter host-bacterial interactions within the intestine, further enhancing morbidity in $\mathrm{Glp}_{2} \mathrm{r}^{-/-}$mice (Lee et al., 2012). In the non-obese diabetic (NOD) mouse, a model of type 1 diabetes, treatment with $\mathrm{h}\left(\mathrm{Gly}^{2}\right) \mathrm{GLP}-2$ once daily for 14 days, increases small intestine length and weight, while also improving jejunal transepithelial resistance compared to treatment with saline. NOD mice treated with a single injection of $\mathrm{h}\left(\mathrm{Gly}^{2}\right) \mathrm{GLP}-2$ appear to have significantly decreased ion conductance in the jejunum (Hadjiyanni et al., 2009).

\section{DISCUSSION}

Agonism of GIPR, GLP-1R, and GLP-2R has a clear clinical impact on nutrient absorption and utilization; however, unraveling endogenous circuits' location in mediating this beneficial effect has been challenging. Clearly, gut hormones represent a signal produced by cells in direct contact with

\section{REFERENCES}

Adriaenssens, A., Lam, B. Y., Billing, L., Skeffington, K., Sewing, S., Reimann, F., et al. (2015). A transcriptome-led exploration of molecular mechanisms regulating somatostatin-producing $\mathrm{D}$-cells in the gastric epithelium. Endocrinology 156, 3924-3936. doi: 10.1210/en.2015-1301

Adriaenssens, A. E., Biggs, E. K., Darwish, T., Tadross, J., Sukthankar, T., Girish, M., et al. (2019). Glucose-dependent insulinotropic polypeptide receptorexpressing cells in the hypothalamus regulate food intake. Cell Metab. 30, 987-996.e6. doi: 10.1016/j.cmet.2019.07.013

Ali, S., Lamont, B. J., Charron, M. J., and Drucker, D. J. (2011). Dual elimination of the glucagon and GLP-1 receptors in mice reveals plasticity in the incretin axis. J. Clin. Invest. 121, 1917-1929. doi: 10.1172/JCI43615

Allin, K. H., Nielsen, T., and Pedersen, O. (2015). Mechanisms in endocrinology: Gut microbiota in patients with type 2 diabetes mellitus. Eur. J. Endocrinol. 172, R167-R177. doi: 10.1530/EJE-14-0874

Andersen, D. B., Grunddal, K. V., Pedersen, J., Kuhre, R. E., Lund, M. L., Holst, J. J., et al. (2021). Using a reporter mouse to map known and novel sites of GLP-1 receptor expression in peripheral tissues of male mice. Endocrinology 162:bqaa246. doi: 10.1210/endocr/bqaa246

Anini, Y., and Brubaker, P. L. (2003). Role of leptin in the regulation of glucagonlike peptide-1 secretion. Diabetes 52, 252-259. doi: 10.2337/diabetes.52.2.252

Argikar, A. A., and Argikar, U. A. (2018). The mesentery: an ADME perspective on a 'new' organ. Drug Metab. Rev. 50, 398-405. doi: 10.1080/03602532.2018. 1484756

Asmar, M., Asmar, A., Simonsen, L., Gasbjerg, L. S., Sparre-Ulrich, A. H., Rosenkilde, M. M., et al. (2017). The gluco- and liporegulatory and vasodilatory effects of glucose-dependent insulinotropic polypeptide (GIP) are abolished by nutrients, bacteria and circulation. Evaluation of models of metabolic disease and aging describe resistance to signaling through established GLP-1R + circuits (Grasset et al., 2017; Varin et al., 2020). It is currently unclear if the resistance to GLP1 is primarily due to impaired receptor expression, reduced signaling in the gut-brain axis and/or intestinal dysbiosis. It is also unknown how much of resistance of endogenous signaling contributes to the heterogeneity observed in metabolic disease and the variable patient responses to pharmacological treatments including DPP4 inhibitors, GLP-1R agonists and bariatric surgery.

As co-agonists are developed and proposed to have greater glycemic and intestinotrophic effects, further understanding of the endogenous signaling and target cells can only improve tailoring and outcomes.

\section{AUTHOR CONTRIBUTIONS}

$\mathrm{NM}, \mathrm{AH}$, and EM: writing-original draft preparation and review and editing. EM: funding acquisition. All authors have read and agreed to the published version of the manuscript.

\section{FUNDING}

NM was the recipient of QEII-GSST and UOHI Cardiac Endowment Fellowship. This research was funded by the NSERC Discovery Grant to EM. EM was the recipient of a Diabetes Canada New Investigator Award, NSERC Discovery Grant RGPIN-2017-05996, and Diabetes Canada New Investigator NC3-18-5425.

an antagonist of the human gip receptor. Diabetes 66, 2363-2371. doi: 10.2337/ db17-0480

Baggio, L. L., and Drucker, D. J. (2007). Biology of incretins: GLP-1 and GIP. Gastroenterology 132, 2131-2157. doi: 10.1053/j.gastro.2007.03.054

Baggio, L. L., Huang, Q., Brown, T. J., and Drucker, D. J. (2004). A recombinant human glucagon-like peptide (GLP)-1-albumin protein (albugon) mimics peptidergic activation of GLP-1 receptor-dependent pathways coupled with satiety, gastrointestinal motility, and glucose homeostasis. Diabetes 53, 24922500. doi: 10.2337/diabetes.53.9.2492

Baldassano, S., Gasbjerg, L. S., Kizilkaya, H. S., Rosenkilde, M. M., Holst, J. J., and Hartmann, B. (2019). Increased body weight and fat mass after subchronic GIP receptor antagonist, but Not GLP-2 receptor antagonist, administration in rats. Front. Endocrinol. (Lausanne) 10:492. doi: 10.3389/fendo.2019.0 0492

Beaudry, J. L., Kaur, K. D., Varin, E. M., Baggio, L. L., Cao, X., Mulvihill, E. E., et al. (2019). Physiological roles of the GIP receptor in murine brown adipose tissue. Mol. Metab. 28, 14-25. doi: 10.1016/j.molmet.2019.08.006

Bernier-Latmani, J., and Petrova, T. V. (2017). Intestinal lymphatic vasculature: structure, mechanisms and functions. Nat. Rev. Gastroenterol. Hepatol. 14, 510-526. doi: 10.1038/nrgastro.2017.79

Boismenu, R., and Havran, W. L. (1994). Modulation of epithelial cell growth by intraepithelial gamma delta T cells. Science 266, 1253-1255. doi: 10.1126/ science.7973709

Borgstrom, B., Dahlqvist, A., Lundh, G., and Sjovall, J. (1957). Studies of intestinal digestion and absorption in the human. J. Clin. Invest. 36, 1521-1536. doi: 10.1172/JCI103549

Boushey, R. P., Yusta, B., and Drucker, D. J. (1999). Glucagon-like peptide 2 decreases mortality and reduces the severity of indomethacin-induced murine 
enteritis. Am. J. Physiol. 277, E937-E947. doi: 10.1152/ajpendo.1999.277.5. E937

Boylan, M. O., Jepeal, L. I., and Wolfe, M. M. (2006). Sp1/Sp3 binding is associated with cell-specific expression of the glucose-dependent insulinotropic polypeptide receptor gene. Am. J. Physiol. Endocrinol. Metab. 290, E1287E1295. doi: 10.1152/ajpendo.00535.2005

Brown, J. C., and Otte, S. C. (1979). GIP and the entero-insular axis. Clin. Endocrinol. Metab. 8, 365-377. doi: 10.1016/s0300-595x(79)80047-x

Brubaker, P. L., Crivici, A., Izzo, A., Ehrlich, P., Tsai, C. H., and Drucker, D. J. (1997). Circulating and tissue forms of the intestinal growth factor, glucagonlike peptide-2. Endocrinology 138, 4837-4843. doi: 10.1210/endo.138.11.5482

Bryant, M. G., Bloom, S. R., Polak, J. M., Hobbs, S., Domschke, W., Domschke, S., et al. (1983). Measurement of gut hormonal peptides in biopsies from human stomach and proximal small intestine. Gut 24, 114-119. doi: 10.1136/gut.24.2. 114

Buchan, A. M., Polak, J. M., Capella, C., Solcia, E., and Pearse, A. G. (1978). Electronimmunocytochemical evidence for the $\mathrm{K}$ cell localization of gastric inhibitory polypeptide (GIP) in man. Histochemistry 56, 37-44. doi: 10.1007/ BF00492251

Bunck, M. C., Corner, A., Eliasson, B., Heine, R. J., Shaginian, R. M., Wu, Y., et al. (2010). One-year treatment with exenatide vs. insulin glargine: effects on postprandial glycemia, lipid profiles, and oxidative stress. Atherosclerosis 212, 223-229. doi: 10.1016/j.atherosclerosis.2010.04.024

Campbell, J. E. (2021). Targeting the GIPR for obesity: To agonize or antagonize? Potential. Mech. Mol. Metab. 46:101139. doi: 10.1016/j.molmet.2020.101139

Campbell, R. M., and Scanes, C. G. (1992). Evolution of the growth hormonereleasing factor (GRF) family of peptides. Growth Regul. 2, 175-191.

Campos, R. V., Lee, Y. C., and Drucker, D. J. (1994). Divergent tissue-specific and developmental expression of receptors for glucagon and glucagon-like peptide-1 in the mouse. Endocrinology 134, 2156-2164. doi: 10.1210/endo.134. 5.8156917

Cheroutre, H., Lambolez, F., and Mucida, D. (2011). The light and dark sides of intestinal intraepithelial lymphocytes. Nat. Rev. Immunol. 11, 445-456. doi: $10.1038 /$ nri3007

Cho, I., Yamanishi, S., Cox, L., Methe, B. A., Zavadil, J., Li, K., et al. (2012). Antibiotics in early life alter the murine colonic microbiome and adiposity. Nature 488, 621-626. doi: 10.1038/nature11400

Christensen, M., Vedtofte, L., Holst, J. J., Vilsboll, T., and Knop, F. K. (2011). Glucose-dependent insulinotropic polypeptide: a bifunctional glucosedependent regulator of glucagon and insulin secretion in humans. Diabetes 60, 3103-3109. doi: 10.2337/db11-0979

Cinci, L., Faussone-Pellegrini, M. S., Rotondo, A., Mule, F., and Vannucchi, M. G. (2011). GLP-2 receptor expression in excitatory and inhibitory enteric neurons and its role in mouse duodenum contractility. Neurogastroenterol. Motil. 23, e383-e392. doi: 10.1111/j.1365-2982.2011.01750.x

Collier, G., McLean, A., and O'Dea, K. (1984). Effect of co-ingestion of fat on the metabolic responses to slowly and rapidly absorbed carbohydrates. Diabetologia 26, 50-54. doi: 10.1007/BF00252263

Collins, J. T., Nguyen, A., and Badireddy, M. (2021). Anatomy, Abdomen and Pelvis, Small Intestine. Treasure Island FL: StatPearls.

Coon, S. D., Schwartz, J. H., Rajendran, V. M., Jepeal, L., and Singh, S. K. (2013). Glucose-dependent insulinotropic polypeptide regulates dipeptide absorption in mouse jejunum. Am. J. Physiol. Gastrointest. Liver Physiol. 305, G678-G684. doi: 10.1152/ajpgi.00098.2013

Covasa, M., Stephens, R. W., Toderean, R., and Cobuz, C. (2019). Intestinal sensing by gut microbiota: targeting gut peptides. Front. Endocrinol. (Lausanne) 10:82. doi: $10.3389 /$ fendo. 2019.00082

Creutzfeldt, W., Ebert, R., Willms, B., Frerichs, H., and Brown, J. C. (1978). Gastric inhibitory polypeptide (GIP) and insulin in obesity: increased response to stimulation and defective feedback control of serum levels. Diabetologia 14, 15-24. doi: 10.1007/BF00429703

D’Alessio, D., Lu, W., Sun, W., Zheng, S., Yang, Q., Seeley, R., et al. (2007). Fasting and postprandial concentrations of GLP-1 in intestinal lymph and portal plasma: evidence for selective release of GLP-1 in the lymph system. Am. J. Physiol. Regul. Integr. Comp. Physiol. 293, R2163-R2169. doi: 10.1152/ajpregu. 00911.2006

Dash, S., Xiao, C., Morgantini, C., Connelly, P. W., Patterson, B. W., and Lewis, G. F. (2014). Glucagon-like peptide-2 regulates release of chylomicrons from the intestine. Gastroenterology 147, 1275-1284 e4. doi: 10.1053/j.gastro.2014. 08.037

Deacon, C. F., Johnsen, A. H., and Holst, J. J. (1995a). Degradation of glucagon-like peptide- 1 by human plasma in vitro yields an $\mathrm{N}$-terminally truncated peptide that is a major endogenous metabolite in vivo. J. Clin. Endocrinol. Metab. 80, 952-957. doi: 10.1210/jcem.80.3.7883856

Deacon, C. F., Johnsen, A. H., and Holst, J. J. (1995b). Human colon produces fully processed glucagon-like peptide-1 (7-36) amide. FEBS Lett. 372, 269-272. doi: 10.1016/0014-5793(95)00983-g

Drucker, D. J., Mojsov, S., and Habener, J. F. (1986). Cell-specific post-translational processing of preproglucagon expressed from a metallothionein-glucagon fusion gene. J. Biol. Chem. 261, 9637-9643.

Drucker, D. J., Philippe, J., Mojsov, S., Chick, W. L., and Habener, J. F. (1987). Glucagon-like peptide I stimulates insulin gene expression and increases cyclic AMP levels in a rat islet cell line. Proc. Natl. Acad. Sci. U.S.A. 84, 3434-3438. doi: $10.1073 /$ pnas.84.10.3434

Drucker, D. J., Shi, Q., Crivici, A., Sumner-Smith, M., Tavares, W., Hill, M., et al. (1997). Regulation of the biological activity of glucagon-like peptide 2 in vivo by dipeptidyl peptidase IV. Nat. Biotechnol. 15, 673-677. doi: 10.1038/nbt0797673

Drucker, D. J., and Yusta, B. (2014). Physiology and pharmacology of the enteroendocrine hormone glucagon-like peptide-2. Annu. Rev. Physiol. 76, 561-583. doi: 10.1146/annurev-physiol-021113-170317

Drucker, D. J., Yusta, B., Boushey, R. P., DeForest, L., and Brubaker, P. L. (1999). Human [Gly2]GLP-2 reduces the severity of colonic injury in a murine model of experimental colitis. Am. J. Physiol. 276, G79-G91. doi: 10.1152/ajpgi.1999. 276.1.G79

Dube, P. E., Forse, C. L., Bahrami, J., and Brubaker, P. L. (2006). The essential role of insulin-like growth factor-1 in the intestinal tropic effects of glucagon-like peptide-2 in mice. Gastroenterology 131, 589-605. doi: 10.1053/j.gastro.2006. 05.055

Eissele, R., Goke, R., Willemer, S., Harthus, H. P., Vermeer, H., Arnold, R., et al. (1992). Glucagon-like peptide-1 cells in the gastrointestinal tract and pancreas of rat, pig and man. Eur. J. Clin. Invest. 22, 283-291. doi: 10.1111/j.1365-2362. 1992.tb01464.x

Ellingsgaard, H., Hauselmann, I., Schuler, B., Habib, A. M., Baggio, L. L., Meier, D. T., et al. (2011). Interleukin-6 enhances insulin secretion by increasing glucagon-like peptide-1 secretion from L cells and alpha cells. Nat. Med. 17, 1481-1489. doi: 10.1038/nm.2513

Ensari, A., and Marsh, M. N. (2018). Exploring the villus. Gastroenterol. Hepatol. Bed Bench 11, 181-190.

Estall, J. L., and Drucker, D. J. (2005). Tales beyond the crypt: glucagon-like peptide-2 and cytoprotection in the intestinal mucosa. Endocrinology 146, 19-21. doi: 10.1210/en.2004-1389

Everard, A., Lazarevic, V., Derrien, M., Girard, M., Muccioli, G. G., Neyrinck, A. M., et al. (2011). Responses of gut microbiota and glucose and lipid metabolism to prebiotics in genetic obese and diet-induced leptin-resistant mice. Diabetes 60, 2775-2786. doi: 10.2337/db11-0227

Flatt, P. R., Kwasowski, P., and Bailey, C. J. (1989). Stimulation of gastric inhibitory polypeptide release in ob/ob mice by oral administration of sugars and their analogues. J. Nutr. 119, 1300-1303. doi: 10.1093/jn/119.9.1300

Flock, G. B., Cao, X., Maziarz, M., and Drucker, D. J. (2013). Activation of enteroendocrine membrane progesterone receptors promotes incretin secretion and improves glucose tolerance in mice. Diabetes 62, 283-290. doi: $10.2337 / \mathrm{db} 12-0601$

Fuchs, S., Yusta, B., Baggio, L. L., Varin, E. M., Matthews, D., and Drucker, D. J. (2020). Loss of Glp2r signaling activates hepatic stellate cells and exacerbates diet-induced steatohepatitis in mice. JCI Insight 5:e136907. doi: 10.1172/jci. insight.136907

Fujita, Y., Asadi, A., Yang, G. K., Kwok, Y. N., and Kieffer, T. J. (2010). Differential processing of pro-glucose-dependent insulinotropic polypeptide in gut. Am. J. Physiol. Gastrointest. Liver Physiol. 298, G608-G614. doi: 10.1152/ajpgi.00024. 2010

Gehart, H., and Clevers, H. (2019). Tales from the crypt: new insights into intestinal stem cells. Nat. Rev. Gastroenterol. Hepatol. 16, 19-34. doi: 10.1038/s41575018-0081-y

Gelling, R. W., Du, X. Q., Dichmann, D. S., Romer, J., Huang, H., Cui, L., et al. (2003). Lower blood glucose, hyperglucagonemia, and pancreatic alpha cell 
hyperplasia in glucagon receptor knockout mice. Proc. Natl. Acad. Sci. U.S.A. 100, 1438-1443. doi: $10.1073 /$ pnas. 0237106100

Ghislain, J., and Poitout, V. (2021). Targeting lipid GPCRs to treat type 2 diabetes mellitus - progress and challenges. Nat. Rev. Endocrinol. 17, 162-175. doi: 10.1038/s41574-020-00459-w

Gorboulev, V., Schurmann, A., Vallon, V., Kipp, H., Jaschke, A., Klessen, D., et al. (2012). $\mathrm{Na}(+)$-D-glucose cotransporter SGLT1 is pivotal for intestinal glucose absorption and glucose-dependent incretin secretion. Diabetes 61, 187-196. doi: $10.2337 / \mathrm{db} 11-1029$

Grasset, E., Puel, A., Charpentier, J., Collet, X., Christensen, J. E., Terce, F., et al. (2017). A Specific gut microbiota dysbiosis of type 2 diabetic mice induces GLP1 resistance through an enteric NO-dependent and gut-brain axis mechanism. Cell Metab. 25, 1075-1090 e5. doi: 10.1016/j.cmet.2017.04.013

Greiner, T. U., and Backhed, F. (2016). Microbial regulation of GLP-1 and L-cell biology. Mol. Metab. 5, 753-758. doi: 10.1016/j.molmet.2016.05.012

Gribble, F. M., and Reimann, F. (2021). Metabolic Messengers: glucagon-like peptide 1. Nat. Metab. 3, 142-148. doi: 10.1038/s42255-020-00327-x

Grigoryan, M., Kedees, M. H., Charron, M. J., Guz, Y., and Teitelman, G. (2012). Regulation of mouse intestinal $\mathrm{L}$ cell progenitors proliferation by the glucagon family of peptides. Endocrinology 153, 3076-3088. doi: 10.1210/en.20121120

Guan, X., Karpen, H. E., Stephens, J., Bukowski, J. T., Niu, S., Zhang, G., et al. (2006). GLP-2 receptor localizes to enteric neurons and endocrine cells expressing vasoactive peptides and mediates increased blood flow. Gastroenterology 130, 150-164. doi: 10.1053/j.gastro.2005.11.005

Guan, X., Stoll, B., Lu, X., Tappenden, K. A., Holst, J. J., Hartmann, B., et al. (2003). GLP-2-mediated up-regulation of intestinal blood flow and glucose uptake is nitric oxide-dependent in TPN-fed piglets 1. Gastroenterology 125, 136-147. doi: 10.1016/s0016-5085(03)00667-x

Hadjiyanni, I., Li, K. K., and Drucker, D. J. (2009). Glucagon-like peptide-2 reduces intestinal permeability but does not modify the onset of type 1 diabetes in the nonobese diabetic mouse. Endocrinology 150, 592-599. doi: 10.1210/en.20081228

Hansen, L., Deacon, C. F., Orskov, C., and Holst, J. J. (1999). Glucagon-like peptide-1-(7-36)amide is transformed to glucagon-like peptide-1-(9-36)amide by dipeptidyl peptidase IV in the capillaries supplying the L cells of the porcine intestine. Endocrinology 140, 5356-5363. doi: 10.1210/endo.140.11. 7143

Hartmann, B., Harr, M. B., Jeppesen, P. B., Wojdemann, M., Deacon, C. F., Mortensen, P. B., et al. (2000). In vivo and in vitro degradation of glucagonlike peptide-2 in humans. J. Clin. Endocrinol. Metab. 85, 2884-2888. doi: 10. 1210/jcem.85.8.6717

Hayashi, H., Nutting, D. F., Fujimoto, K., Cardelli, J. A., Black, D., and Tso, P. (1990). Transport of lipid and apolipoproteins A-I and A-IV in intestinal lymph of the rat. J. Lipid Res. 31, 1613-1625.

He, S., Kahles, F., Rattik, S., Nairz, M., McAlpine, C. S., Anzai, A., et al. (2019). Gut intraepithelial T cells calibrate metabolism and accelerate cardiovascular disease. Nature 566, 115-119. doi: 10.1038/s41586-018-0849-9

Herrmann, C., Goke, R., Richter, G., Fehmann, H. C., Arnold, R., and Goke, B. (1995). Glucagon-like peptide-1 and glucose-dependent insulin-releasing polypeptide plasma levels in response to nutrients. Digestion 56, 117-126. doi: $10.1159 / 000201231$

Higashimoto, Y., and Liddle, R. A. (1993). Isolation and characterization of the gene encoding rat glucose-dependent insulinotropic peptide. Biochem. Biophys. Res. Commun. 193, 182-190. doi: 10.1006/bbrc.1993.1607

Higashimoto, Y., Opara, E. C., and Liddle, R. A. (1995). Dietary regulation of glucose-dependent insulinotropic peptide (GIP) gene expression in rat small intestine. Comp. Biochem. Physiol. C Pharmacol. Toxicol. Endocrinol. 110, 207-214. doi: 10.1016/0742-8413(94)00087-q

Higashimoto, Y., Simchock, J., and Liddle, R. A. (1992). Molecular cloning of rat glucose-dependent insulinotropic peptide (GIP). Biochim. Biophys. Acta 1132, 72-74. doi: 10.1016/0167-4781(92)90054-4

Holst, J. J., Orskov, C., Nielsen, O. V., and Schwartz, T. W. (1987). Truncated glucagon-like peptide I, an insulin-releasing hormone from the distal gut. FEBS Lett. 211, 169-174. doi: 10.1016/0014-5793(87)81430-8

Holst, J. J., Windelov, J. A., Boer, G. A., Pedersen, J., Svendsen, B., Christensen, M., et al. (2016). Searching for the physiological role of glucose-dependent insulinotropic polypeptide. J. Diabetes Investig. 7(Suppl 1), 8-12. doi: 10.1111/ jdi. 12488

Hsieh, J., Longuet, C., Baker, C. L., Qin, B., Federico, L. M., Drucker, D. J., et al. (2010). The glucagon-like peptide 1 receptor is essential for postprandial lipoprotein synthesis and secretion in hamsters and mice. Diabetologia 53, 552-561. doi: 10.1007/s00125-009-1611-5

Hsieh, J., Longuet, C., Maida, A., Bahrami, J., Xu, E., Baker, C. L., et al. (2009). Glucagon-like peptide-2 increases intestinal lipid absorption and chylomicron production via CD36. Gastroenterology 137, 997-1005, 1005.e1-4. doi: 10.1053/ j.gastro.2009.05.051

Hsieh, J., Trajcevski, K. E., Farr, S. L., Baker, C. L., Lake, E. J., Taher, J., et al. (2015). Glucagon-like peptide 2 (GLP-2) stimulates postprandial chylomicron production and postabsorptive release of intestinal triglyceride storage pools via induction of nitric oxide signaling in male hamsters and mice. Endocrinology 156, 3538-3547. doi: 10.1210/EN.2015-1110

Hwang, I., Park, Y. J., Kim, Y. R., Kim, Y. N., Ka, S., Lee, H. Y., et al. (2015). Alteration of gut microbiota by vancomycin and bacitracin improves insulin resistance via glucagon-like peptide 1 in diet-induced obesity. FASEB J. 29, 2397-2411. doi: 10.1096/fj.14-265983

Ikeguchi, E., Harada, N., Kanemaru, Y., Sankoda, A., Yamane, S., Iwasaki, K., et al. (2018). Transcriptional factor Pdxl is involved in age-related GIP hypersecretion in mice. Am. J. Physiol. Gastrointest. Liver Physiol. 315, G272G282. doi: 10.1152/ajpgi.00054.2018

Iwasaki, K., Harada, N., Sasaki, K., Yamane, S., Iida, K., Suzuki, K., et al. (2015). Free fatty acid receptor GPR120 is highly expressed in enteroendocrine K cells of the upper small intestine and has a critical role in GIP secretion after fat ingestion. Endocrinology 156, 837-846. doi: 10.1210/en.2014-1653

Jeppesen, P. B., Hartmann, B., Thulesen, J., Hansen, B. S., Holst, J. J., Poulsen, S. S., et al. (2000). Elevated plasma glucagon-like peptide 1 and 2 concentrations in ileum resected short bowel patients with a preserved colon. Gut 47, 370-376. doi: 10.1136/gut.47.3.370

Jeppesen, P. B., Sanguinetti, E. L., Buchman, A., Howard, L., Scolapio, J. S., Ziegler, T. R., et al. (2005). Teduglutide (ALX-0600), a dipeptidyl peptidase IV resistant glucagon-like peptide 2 analogue, improves intestinal function in short bowel syndrome patients. Gut 54, 1224-1231. doi: 10.1136/gut.2004.061440

Jepsen, S. L., Grunddal, K. V., Wewer Albrechtsen, N. J., Engelstoft, M. S., Gabe, M. B. N., Jensen, E. P., et al. (2019). Paracrine crosstalk between intestinal Land D-cells controls secretion of glucagon-like peptide-1 in mice. Am. J. Physiol. Endocrinol. Metab. 317, E1081-E1093. doi: 10.1152/ajpendo.00239.2019

Jorsal, T., Rhee, N. A., Pedersen, J., Wahlgren, C. D., Mortensen, B., Jepsen, S. L., et al. (2018). Enteroendocrine $\mathrm{K}$ and $\mathrm{L}$ cells in healthy and type 2 diabetic individuals. Diabetologia 61, 284-294. doi: 10.1007/s00125-017-4450-9

Kahles, F., Meyer, C., Mollmann, J., Diebold, S., Findeisen, H. M., Lebherz, C., et al. (2014). GLP-1 secretion is increased by inflammatory stimuli in an IL6-dependent manner, leading to hyperinsulinemia and blood glucose lowering. Diabetes 63, 3221-3229. doi: 10.2337/db14-0100

Kedees, M. H., Guz, Y., Grigoryan, M., and Teitelman, G. (2013). Functional activity of murine intestinal mucosal cells is regulated by the glucagon-like peptide-1 receptor. Peptides 48, 36-44. doi: 10.1016/j.peptides.2013.07.022

Kiela, P. R., and Ghishan, F. K. (2016). Physiology of Intestinal Absorption and Secretion. Best Pract. Res. Clin. Gastroenterol. 30, 145-159. doi: 10.1016/j.bpg. 2016.02.007

Kim, S. J., Nian, C., and McIntosh, C. H. (2007a). Activation of lipoprotein lipase by glucose-dependent insulinotropic polypeptide in adipocytes. A role for a protein kinase B, LKB1, and AMP-activated protein kinase cascade. J. Biol. Chem. 282, 8557-8567. doi: 10.1074/jbc.M609088200

Kim, S. J., Nian, C., and McIntosh, C. H. (2007b). Resistin is a key mediator of glucose-dependent insulinotropic polypeptide (GIP) stimulation of lipoprotein lipase (LPL) activity in adipocytes. J. Biol. Chem. 282, 34139-34147. doi: 10. 1074/jbc.M704896200

Kim, S. J., Nian, C., and McIntosh, C. H. (2010). GIP increases human adipocyte LPL expression through CREB and TORC2-mediated trans-activation of the LPL gene. J. Lipid Res. 51, 3145-3157. doi: 10.1194/jlr.M006841

Knudsen, L. B., and Pridal, L. (1996). Glucagon-like peptide-1-(9-36) amide is a major metabolite of glucagon-like peptide-1-(7-36) amide after in vivo administration to dogs, and it acts as an antagonist on the pancreatic receptor. Eur. J. Pharmacol. 318, 429-435. doi: 10.1016/s0014-2999(96)00795-9 
Koehler, J. A., Baggio, L. L., Yusta, B., Longuet, C., Rowland, K. J., Cao, X., et al. (2015). GLP-1R agonists promote normal and neoplastic intestinal growth through mechanisms requiring Fgf7. Cell Metab. 21, 379-391. doi: 10.1016/j. cmet.2015.02.005

Koehler, J. A., Harper, W., Barnard, M., Yusta, B., and Drucker, D. J. (2008). Glucagon-like peptide-2 does not modify the growth or survival of murine or human intestinal tumor cells. Cancer Res. 68, 7897-7904. doi: 10.1158/00085472.CAN-08-0029

Kuhre, R. E., Gribble, F. M., Hartmann, B., Reimann, F., Windelov, J. A., Rehfeld, J. F., et al. (2014). Fructose stimulates GLP-1 but not GIP secretion in mice, rats, and humans. Am. J. Physiol. Gastrointest. Liver Physiol. 306, G622-G630. doi: 10.1152/ajpgi.00372.2013

Lamont, B. J., Li, Y., Kwan, E., Brown, T. J., Gaisano, H., and Drucker, D. J. (2012). Pancreatic GLP-1 receptor activation is sufficient for incretin control of glucose metabolism in mice. J. Clin. Invest. 122, 388-402. doi: 10.1172/JCI42497

Lankat-Buttgereit, B., and Goke, B. (1997). Cloning and characterization of the $5^{\prime}$ flanking sequences (promoter region) of the human GLP-1 receptor gene. Peptides 18, 617-624. doi: 10.1016/s0196-9781(97)00001-6

Lee, S. J., Lee, J., Li, K. K., Holland, D., Maughan, H., Guttman, D. S., et al. (2012). Disruption of the murine Glp2r impairs Paneth cell function and increases susceptibility to small bowel enteritis. Endocrinology 153, 1141-1151. doi: 10. 1210/en.2011-1954

Li, F., Lu, L., Peng, Y., Zhang, Y., Gao, J., Zhou, D., et al. (2017). Increased GLP2R expression in gastric chief cells of patients with severe obesity regardless of diabetes status. Int. J. Obes. (Lond) 41, 1303-1305. doi: 10.1038/ijo.2017.77

Lu, W. J., Yang, Q., Sun, W., Woods, S. C., D'Alessio, D., and Tso, P. (2007). The regulation of the lymphatic secretion of glucagon-like peptide-1 (GLP-1) by intestinal absorption of fat and carbohydrate. Am. J. Physiol. Gastrointest. Liver Physiol. 293, G963-G971. doi: 10.1152/ajpgi.00146.2007

Lu, W. J., Yang, Q., Sun, W., Woods, S. C., D’Alessio, D., and Tso, P. (2008). Using the lymph fistula rat model to study the potentiation of GIP secretion by the ingestion of fat and glucose. Am. J. Physiol. Gastrointest. Liver Physiol. 294, G1130-G1138. doi: 10.1152/ajpgi.00400.2007

Lu, W. J., Yang, Q., Yang, L., Lee, D., D’Alessio, D., and Tso, P. (2012). Chylomicron formation and secretion is required for lipid-stimulated release of incretins GLP-1 and GIP. Lipids 47, 571-580. doi: 10.1007/s11745-011-3650-1

Lund, A., Bagger, J. I., Wewer Albrechtsen, N. J., Christensen, M., Grondahl, M., Hartmann, B., et al. (2016). Evidence of extrapancreatic glucagon secretion in man. Diabetes 65, 585-597. doi: 10.2337/db15-1541

Markovic, M. A., and Brubaker, P. L. (2019). The roles of glucagon-like peptide-2 and the intestinal epithelial insulin-like growth factor-1 receptor in regulating microvillus length. Sci. Rep. 9:13010. doi: 10.1038/s41598-019-49510-5

Martchenko, S. E., Martchenko, A., Cox, B. J., Naismith, K., Waller, A., Gurges, P., et al. (2020). Circadian GLP-1 secretion in mice is dependent on the intestinal microbiome for maintenance of diurnal metabolic homeostasis. Diabetes 69, 2589-2602. doi: $10.2337 / \mathrm{db} 20-0262$

Martin, A. M., Sun, E. W., Rogers, G. B., and Keating, D. J. (2019). The influence of the gut microbiome on host metabolism through the regulation of gut hormone release. Front. Physiol. 10:428. doi: 10.3389/fphys.2019.00428

Matikainen, N., Bjornson, E., Soderlund, S., Boren, C., Eliasson, B., Pietilainen, K. H., et al. (2016). Minor contribution of endogenous GLP-1 and GLP-2 to postprandial lipemia in obese men. PLoS One 11:e0145890. doi: 10.1371/ journal.pone. 0145890

McCullough, A. J., Miller, L. J., Service, F. J., and Go, V. L. (1983). Effect of graded intraduodenal glucose infusions on the release and physiological action of gastric inhibitory polypeptide. J. Clin. Endocrinol. Metab. 56, 234-241. doi: 10.1210/jcem-56-2-234

McLean, B. A., Wong, C. K., Campbell, J. E., Hodson, D. J., Trapp, S., and Drucker, D. J. (2021). Revisiting the complexity of GLP-1 action from sites of synthesis to receptor activation. Endocr. Rev. 42, 101-132. doi: 10.1210/endrev/bnaa032

Meek, C. L., Lewis, H. B., Burling, K., Reimann, F., and Gribble, F. (2021). Expected values for gastrointestinal and pancreatic hormone concentrations in healthy volunteers in the fasting and postprandial state. Ann. Clin. Biochem. 58, 108-116. doi: 10.1177/0004563220975658

Meier, J. J., Goetze, O., Anstipp, J., Hagemann, D., Holst, J. J., Schmidt, W. E., et al. (2004a). Gastric inhibitory polypeptide does not inhibit gastric emptying in humans. Am. J. Physiol. Endocrinol. Metab. 286, E621-E625. doi: 10.1152/ ajpendo.00499.2003
Meier, J. J., Nauck, M. A., Kranz, D., Holst, J. J., Deacon, C. F., Gaeckler, D., et al. (2004b). Secretion, degradation, and elimination of glucagon-like peptide 1 and gastric inhibitory polypeptide in patients with chronic renal insufficiency and healthy control subjects. Diabetes 53, 654-662. doi: 10.2337/diabetes.53. 3.654

Mojsov, S., Heinrich, G., Wilson, I. B., Ravazzola, M., Orci, L., and Habener, J. F. (1986). Preproglucagon gene expression in pancreas and intestine diversifies at the level of post-translational processing. J. Biol. Chem. 261, 11880-11889.

Moran, B. M., Miskelly, M. G., Abdel-Wahab, Y. H. A., Flatt, P. R., and McKillop, A. M. (2019). Zinc-induced activation of GPR39 regulates glucose homeostasis through glucose-dependent insulinotropic polypeptide secretion from enteroendocrine K-cells. Biol. Chem. 400, 1023-1033. doi: 10.1515/hsz2018-0393

Moriya, R., Shirakura, T., Ito, J., Mashiko, S., and Seo, T. (2009). Activation of sodium-glucose cotransporter 1 ameliorates hyperglycemia by mediating incretin secretion in mice. Am. J. Physiol. Endocrinol. Metab. 297, E1358-E1365. doi: 10.1152/ajpendo.00412.2009

Munroe, D. G., Gupta, A. K., Kooshesh, F., Vyas, T. B., Rizkalla, G., Wang, H., et al. (1999). Prototypic G protein-coupled receptor for the intestinotrophic factor glucagon-like peptide 2. Proc. Natl. Acad. Sci. U.S.A. 96, 1569-1573. doi: 10.1073/pnas.96.4.1569

Nasteska, D., Harada, N., Suzuki, K., Yamane, S., Hamasaki, A., Joo, E., et al. (2014). Chronic reduction of GIP secretion alleviates obesity and insulin resistance under high-fat diet conditions. Diabetes 63, 2332-2343. doi: 10.2337/db131563

Nelson, D. W., Murali, S. G., Liu, X., Koopmann, M. C., Holst, J. J., and Ney, D. M. (2008). Insulin-like growth factor I and glucagon-like peptide-2 responses to fasting followed by controlled or ad libitum refeeding in rats. Am. J. Physiol. Regul. Integr. Comp. Physiol. 294, R1175-R1184. doi: 10.1152/ajpregu.00238. 2007

Nelson, D. W., Sharp, J. W., Brownfield, M. S., Raybould, H. E., and Ney, D. M. (2007). Localization and activation of glucagon-like peptide-2 receptors on vagal afferents in the rat. Endocrinology 148, 1954-1962. doi: 10.1210/en.20061232

Nguyen, A. T., Mandard, S., Dray, C., Deckert, V., Valet, P., Besnard, P., et al. (2014). Lipopolysaccharides-mediated increase in glucose-stimulated insulin secretion: involvement of the GLP-1 pathway. Diabetes 63, 471-482. doi: 10. 2337/db13-0903

Ogata, H., Seino, Y., Harada, N., Iida, A., Suzuki, K., Izumoto, T., et al. (2014). KATP channel as well as SGLT1 participates in GIP secretion in the diabetic state. J. Endocrinol. 222, 191-200. doi: 10.1530/JOE-14-0161

Orskov, C., Bersani, M., Johnsen, A. H., Hojrup, P., and Holst, J. J. (1989a). Complete sequences of glucagon-like peptide-1 from human and pig small intestine. J. Biol. Chem. 264, 12826-12829.

Orskov, C., Buhl, T., Rabenhoj, L., Kofod, H., and Holst, J. J. (1989b). Carboxypeptidase-B-like processing of the C-terminus of glucagon-like peptide-2 in pig and human small intestine. FEBS Lett. 247, 193-196. doi: 10.1016/0014-5793(89)81332-8

Orskov, C., Hartmann, B., Poulsen, S. S., Thulesen, J., Hare, K. J., and Holst, J. J. (2005). GLP-2 stimulates colonic growth via KGF, released by subepithelial myofibroblasts with GLP-2 receptors. Regul. Pept. 124, 105-112. doi: 10.1016/j. regpep.2004.07.009

Orskov, C., Holst, J. J., Knuhtsen, S., Baldissera, F. G., Poulsen, S. S., and Nielsen, O. V. (1986). Glucagon-like peptides GLP-1 and GLP-2, predicted products of the glucagon gene, are secreted separately from pig small intestine but not pancreas. Endocrinology 119, 1467-1475. doi: 10.1210/endo-119-41467

Pais, R., Gribble, F. M., and Reimann, F. (2016). Stimulation of incretin secreting cells. Ther. Adv. Endocrinol. Metab. 7, 24-42. doi: 10.1177/2042018815618177

Paternoster, S., and Falasca, M. (2018). Dissecting the physiology and pathophysiology of glucagon-like peptide-1. Front. Endocrinol. (Lausanne) 9:584. doi: 10.3389/fendo.2018.00584

Pavlic, M., Xiao, C., Szeto, L., Patterson, B. W., and Lewis, G. F. (2010). Insulin acutely inhibits intestinal lipoprotein secretion in humans in part by suppressing plasma free fatty acids. Diabetes $59,580-587$. doi: $10.2337 / \mathrm{db} 09-$ 1297

Pedersen, J., Pedersen, N. B., Brix, S. W., Grunddal, K. V., Rosenkilde, M. M., Hartmann, B., et al. (2015). The glucagon-like peptide 2 receptor is expressed in 
enteric neurons and not in the epithelium of the intestine. Peptides 67, 20-28. doi: 10.1016/j.peptides.2015.02.007

Pedersen, J., Ugleholdt, R. K., Jorgensen, S. M., Windelov, J. A., Grunddal, K. V., Schwartz, T. W., et al. (2013). Glucose metabolism is altered after loss of L cells and alpha-cells but not influenced by loss of K cells. Am. J. Physiol. Endocrinol. Metab. 304, E60-E73. doi: 10.1152/ajpendo.00547.2011

Pederson, R. A., Schubert, H. E., and Brown, J. C. (1975). Gastric inhibitory polypeptide. Its physiologic release and insulinotropic action in the dog. Diabetes 24, 1050-1056. doi: 10.2337/diab.24.12.1050

Psichas, A., Glass, L. L., Sharp, S. J., Reimann, F., and Gribble, F. M. (2016). Galanin inhibits GLP-1 and GIP secretion via the GAL1 receptor in enteroendocrine L and K cells. Br. J. Pharmacol. 173, 888-898. doi: 10.1111/bph.13407

Psichas, A., Larraufie, P. F., Goldspink, D. A., Gribble, F. M., and Reimann, F. (2017). Chylomicrons stimulate incretin secretion in mouse and human cells. Diabetologia 60, 2475-2485. doi: 10.1007/s00125-017-4420-2

Pujadas, G., Varin, E. M., Baggio, L. L., Mulvihill, E. E., Bang, K. W. A., Koehler, J. A., et al. (2020). The gut hormone receptor GIPR links energy availability to the control of hematopoiesis. Mol Metab. 39:101008. doi: 10.1016/j.molmet. 2020.101008

Pyke, C., Heller, R. S., Kirk, R. K., Orskov, C., Reedtz-Runge, S., Kaastrup, P., et al. (2014). GLP-1 receptor localization in monkey and human tissue: novel distribution revealed with extensively validated monoclonal antibody. Endocrinology 155, 1280-1290. doi: 10.1210/en.2013-1934

Ranganath, L. R., Beety, J. M., and Morgan, L. M. (1999). Inhibition of insulin, glucose-dependent insulinotropic polypeptide (GIP) and glucagon-like peptide-1 (GLP-1) secretion by octreotide has no effect on post-heparin plasma lipoprotein lipase activity. Horm. Metab. Res. 31, 262-266. doi: 10.1055/s-2007978729

Reimann, F., Diakogiannaki, E., Moss, C. E., and Gribble, F. M. (2020). Cellular mechanisms governing glucose-dependent insulinotropic polypeptide secretion. Peptides 125:170206. doi: 10.1016/j.peptides.2019.170206

Reimann, F., Habib, A. M., Tolhurst, G., Parker, H. E., Rogers, G. J., and Gribble, F. M. (2008). Glucose sensing in L cells: a primary cell study. Cell Metab. 8, 532-539. doi: 10.1016/j.cmet.2008.11.002

Ribeiro-Parenti, L., Jarry, A. C., Cavin, J. B., Willemetz, A., Le Beyec, J., Sannier, A., et al. (2021). Bariatric surgery induces a new gastric mucosa phenotype with increased functional glucagon-like peptide-1 expressing cells. Nat. Commun. 12:110. doi: 10.1038/s41467-020-20301-1

Richards, P., Parker, H. E., Adriaenssens, A. E., Hodgson, J. M., Cork, S. C., Trapp, S., et al. (2014). Identification and characterization of GLP-1 receptorexpressing cells using a new transgenic mouse model. Diabetes 63, 1224-1233. doi: $10.2337 / \mathrm{db} 13-1440$

Roberge, J. N., and Brubaker, P. L. (1993). Regulation of intestinal proglucagonderived peptide secretion by glucose-dependent insulinotropic peptide in a novel enteroendocrine loop. Endocrinology 133, 233-240. doi: 10.1210/endo. 133.1.8319572

Roberge, J. N., Gronau, K. A., and Brubaker, P. L. (1996). Gastrin-releasing peptide is a novel mediator of proximal nutrient-induced proglucagon-derived peptide secretion from the distal gut. Endocrinology 137, 2383-2388. doi: 10.1210/endo. 137.6.8641190

Robertson, M. D., Parkes, M., Warren, B. F., Ferguson, D. J., Jackson, K. G., Jewell, D. P., et al. (2003). Mobilisation of enterocyte fat stores by oral glucose in humans. Gut 52, 834-839. doi: 10.1136/gut.52.6.834

Rocca, A. S., and Brubaker, P. L. (1999). Role of the vagus nerve in mediating proximal nutrient-induced glucagon-like peptide-1 secretion. Endocrinology 140, 1687-1694. doi: 10.1210/endo.140.4.6643

Rowland, K. J., Trivedi, S., Lee, D., Wan, K., Kulkarni, R. N., Holzenberger, M., et al. (2011). Loss of glucagon-like peptide-2-induced proliferation following intestinal epithelial insulin-like growth factor-1-receptor deletion. Gastroenterology 141, 2166-2175.e7. doi: 10.1053/j.gastro.2011.09.014

Sato, S., Hokari, R., Kurihara, C., Sato, H., Narimatsu, K., Hozumi, H., et al. (2013). Dietary lipids and sweeteners regulate glucagon-like peptide-2 secretion. Am. J. Physiol. Gastrointest. Liver Physiol. 304, G708-G714. doi: 10.1152/ajpgi.00282. 2012

Schwartz, E. A., Koska, J., Mullin, M. P., Syoufi, I., Schwenke, D. C., and Reaven, P. D. (2010). Exenatide suppresses postprandial elevations in lipids and lipoproteins in individuals with impaired glucose tolerance and recent onset type 2 diabetes mellitus. Atherosclerosis 212, 217-222. doi: 10.1016/j. atherosclerosis.2010.05.028

Schwartz, S. L., Ratner, R. E., Kim, D. D., Qu, Y., Fechner, L. L., Lenox, S. M., et al. (2008). Effect of exenatide on 24-hour blood glucose profile compared with placebo in patients with type 2 diabetes: a randomized, double-blind, twoarm, parallel-group, placebo-controlled, 2-week study. Clin. Ther. 30, 858-867. doi: 10.1016/j.clinthera.2008.05.004

Seino, Y., Ogata, H., Maekawa, R., Izumoto, T., Iida, A., Harada, N., et al. (2015). Fructose induces glucose-dependent insulinotropic polypeptide, glucagon-like peptide-1 and insulin secretion: Role of adenosine triphosphatesensitive $\mathrm{K}(+)$ channels. J. Diabetes Investig. 6, 522-526. doi: 10.1111/jdi.1 2356

Sherman, S. K., Carr, J. C., Wang, D., O’Dorisio, M. S., O’Dorisio, T. M., and Howe, J. R. (2013). Gastric inhibitory polypeptide receptor (GIPR) is a promising target for imaging and therapy in neuroendocrine tumors. Surgery 154, 12061213; discussion1214. doi: 10.1016/j.surg.2013.04.052

Shibue, K., Yamane, S., Harada, N., Hamasaki, A., Suzuki, K., Joo, E., et al. (2015). Fatty acid-binding protein 5 regulates diet-induced obesity via GIP secretion from enteroendocrine $\mathrm{K}$ cells in response to fat ingestion. Am. J. Physiol. Endocrinol. Metab. 308, E583-E591. doi: 10.1152/ajpendo.00543.2014

Shin, E. D., Estall, J. L., Izzo, A., Drucker, D. J., and Brubaker, P. L. (2005). Mucosal adaptation to enteral nutrients is dependent on the physiologic actions of glucagon-like peptide-2 in mice. Gastroenterology 128, 1340-1353. doi: 10. 1053/j.gastro.2005.02.033

Simon, M. C., Strassburger, K., Nowotny, B., Kolb, H., Nowotny, P., Burkart, V., et al. (2015). Intake of Lactobacillus reuteri improves incretin and insulin secretion in glucose-tolerant humans: a proof of concept. Diabetes Care 38, 1827-1834. doi: 10.2337/dc14-2690

Sivitz, W. I., Walsh, S. A., Morgan, D. A., Thomas, M. J., and Haynes, W. G. (1997). Effects of leptin on insulin sensitivity in normal rats. Endocrinology 138, 3395-3401. doi: 10.1210/endo.138.8.5327

Spreckley, E., and Murphy, K. G. (2015). The L-cell in nutritional sensing and the regulation of appetite. Front. Nutr. 2:23. doi: 10.3389/fnut.2015.00023

Stahel, P., Xiao, C., Davis, X., Tso, P., and Lewis, G. F. (2019). Glucose and GLP-2 (Glucagon-Like Peptide-2) mobilize intestinal triglyceride by distinct mechanisms. Arterioscler. Thromb. Vasc. Biol. 39, 1565-1573. doi: 10.1161/ ATVBAHA.119.313011

Suzuki, K., Harada, N., Yamane, S., Nakamura, Y., Sasaki, K., Nasteska, D., et al. (2013). Transcriptional regulatory factor X6 (Rfx6) increases gastric inhibitory polypeptide (GIP) expression in enteroendocrine K-cells and is involved in GIP hypersecretion in high fat diet-induced obesity. J. Biol. Chem. 288, 1929-1938. doi: 10.1074/jbc.M112.423137

Sykes, S., Morgan, L. M., English, J., and Marks, V. (1980). Evidence for preferential stimulation of gastric inhibitory polypeptide secretion in the rat by actively transported carbohydrates and their analogues. J. Endocrinol. 85, 201-207. doi: $10.1677 /$ joe. 0.0850201

Szalowska, E., Meijer, K., Kloosterhuis, N., Razaee, F., Priebe, M., and Vonk, R. J. (2011). Sub-chronic administration of stable GIP analog in mice decreases serum LPL activity and body weight. Peptides 32, 938-945. doi: 10.1016/j. peptides.2011.02.011

Takeda, J., Seino, Y., Tanaka, K., Fukumoto, H., Kayano, T., Takahashi, H., et al. (1987). Sequence of an intestinal cDNA encoding human gastric inhibitory polypeptide precursor. Proc. Natl. Acad. Sci. U.S.A. 84, 7005-7008. doi: 10.1073/ pnas.84.20.7005

Tseng, C. C., Jarboe, L. A., Landau, S. B., Williams, E. K., and Wolfe, M. M. (1993). Glucose-dependent insulinotropic peptide: structure of the precursor and tissue-specific expression in rat. Proc. Natl. Acad. Sci. U.S.A. 90, 1992-1996. doi: $10.1073 /$ pnas.90.5.1992

Tso, P., Balint, J. A., Bishop, M. B., and Rodgers, J. B. (1981). Acute inhibition of intestinal lipid transport by Pluronic L-81 in the rat. Am. J. Physiol. 241, G487-G497. doi: 10.1152/ajpgi.1981.241.6.G487

Turner, J. R. (2009). Intestinal mucosal barrier function in health and disease. Nat. Rev. Immunol. 9, 799-809. doi: 10.1038/nri2653

Ugleholdt, R., Poulsen, M. L., Holst, P. J., Irminger, J. C., Orskov, C., Pedersen, J., et al. (2006). Prohormone convertase $1 / 3$ is essential for processing of the glucose-dependent insulinotropic polypeptide precursor. J. Biol. Chem. 281, 11050-11057. doi: 10.1074/jbc.M601203200 
Usdin, T. B., Mezey, E., Button, D. C., Brownstein, M. J., and Bonner, T. I. (1993). Gastric inhibitory polypeptide receptor, a member of the secretin-vasoactive intestinal peptide receptor family, is widely distributed in peripheral organs and the brain. Endocrinology 133, 2861-2870. doi: 10.1210/endo.133.6.8243312

Utzschneider, K. M., Kratz, M., Damman, C. J., and Hullar, M. (2016). Mechanisms linking the gut microbiome and glucose metabolism. J. Clin. Endocrinol. Metab. 101, 1445-1454. doi: 10.1210/jc.2015-4251

Varin, E. M., Hanson, A. A., Beaudry, J. L., Nguyen, M. A., Cao, X., Baggio, L. L., et al. (2020). ). Hematopoietic cell- versus enterocyte-derived dipeptidyl peptidase-4 differentially regulates triglyceride excursion in mice. JCI Insight 5:e140418. doi: 10.1172/jci.insight.140418

Vilsboll, T., Krarup, T., Deacon, C. F., Madsbad, S., and Holst, J. J. (2001). Reduced postprandial concentrations of intact biologically active glucagon-like peptide 1 in type 2 diabetic patients. Diabetes 50, 609-613. doi: 10.2337/diabetes.50.3.609

Walsh, N. A., Yusta, B., DaCambra, M. P., Anini, Y., Drucker, D. J., and Brubaker, P. L. (2003). Glucagon-like peptide-2 receptor activation in the rat intestinal mucosa. Endocrinology 144, 4385-4392. doi: 10.1210/en.2003-0309

Wismann, P., Barkholt, P., Secher, T., Vrang, N., Hansen, H. B., Jeppesen, P. B., et al. (2017). The endogenous preproglucagon system is not essential for gut growth homeostasis in mice. Mol. Metab. 6, 681-692. doi: 10.1016/j.molmet. 2017.04.007

Wu, J., Ren, W., Li, L., Luo, M., Xu, K., Shen, J., et al. (2018). Effect of aging and glucagon-like peptide 2 on intestinal microbiota in SD rats. Aging Dis. 9, 566-577. doi: 10.14336/AD.2017.1001

Xiao, C., Bandsma, R. H., Dash, S., Szeto, L., and Lewis, G. F. (2012). Exenatide, a glucagon-like peptide-1 receptor agonist, acutely inhibits intestinal lipoprotein production in healthy humans. Arterioscler Thromb. Vasc. Biol. 32, 1513-1519. doi: 10.1161/ATVBAHA.112.246207

Xiao, C., Stahel, P., Carreiro, A. L., Hung, Y. H., Dash, S., Bookman, I., et al. (2019). Oral glucose mobilizes triglyceride stores from the human intestine. Cell Mol. Gastroenterol. Hepatol. 7, 313-337. doi: 10.1016/j.jcmgh.2018.10.002

Yamada, Y., Hayami, T., Nakamura, K., Kaisaki, P. J., Someya, Y., Wang, C. Z., et al. (1995). Human gastric inhibitory polypeptide receptor: cloning of the gene (GIPR) and cDNA. Genomics 29, 773-776. doi: 10.1006/geno.1995.9937

Yamane, S., Harada, N., Hamasaki, A., Muraoka, A., Joo, E., Suzuki, K., et al. (2012). Effects of glucose and meal ingestion on incretin secretion in Japanese subjects with normal glucose tolerance. J. Diabetes Investig. 3, 80-85. doi: 10.1111/j. 2040-1124.2011.00143.x
Yoon, H. S., Cho, C. H., Yun, M. S., Jang, S. J., You, H. J., Kim, J. H., et al. (2021). Akkermansia muciniphila secretes a glucagon-like peptide-1-inducing protein that improves glucose homeostasis and ameliorates metabolic disease in mice. Nat. Microbiol. 6, 563-573. doi: 10.1038/s41564-021-00880-5

Yusta, B., Baggio, L. L., Koehler, J., Holland, D., Cao, X., Pinnell, L. J., et al. (2015). GLP-1R agonists modulate enteric immune responses through the intestinal intraepithelial lymphocyte GLP-1R. Diabetes 64, 2537-2549. doi: 10.2337/db141577

Yusta, B., Boushey, R. P., and Drucker, D. J. (2000). The glucagon-like peptide-2 receptor mediates direct inhibition of cellular apoptosis via a cAMP-dependent protein kinase-independent pathway. J. Biol. Chem. 275, 35345-35352. doi: 10.1074/jbc.M005510200

Yusta, B., Matthews, D., Koehler, J. A., Pujadas, G., Kaur, K. D., and Drucker, D. J. (2019). Localization of glucagon-like peptide-2 receptor expression in the mouse. Endocrinology 160, 1950-1963. doi: 10.1210/en.2019-0 0398

Zietek, T., and Rath, E. (2016). Inflammation meets metabolic disease: gut feeling mediated by GLP-1. Front. Immunol. 7:154. doi: 10.3389/fimmu.2016.00154

Conflict of Interest: The EM lab receives funding from the Merck IISP program for preclinical studies unrelated to this work.

The remaining authors declare that the research was conducted in the absence of any commercial or financial relationships that could be construed as a potential conflict of interest.

Publisher's Note: All claims expressed in this article are solely those of the authors and do not necessarily represent those of their affiliated organizations, or those of the publisher, the editors and the reviewers. Any product that may be evaluated in this article, or claim that may be made by its manufacturer, is not guaranteed or endorsed by the publisher.

Copyright (c) 2021 Morrow, Hanson and Mulvihill. This is an open-access article distributed under the terms of the Creative Commons Attribution License (CC BY). The use, distribution or reproduction in other forums is permitted, provided the original author(s) and the copyright owner(s) are credited and that the original publication in this journal is cited, in accordance with accepted academic practice. No use, distribution or reproduction is permitted which does not comply with these terms. 